\title{
Intenzifikacija fotokatalitičkih procesa za obradu voda i otpadnih voda
}

\author{
1. E. Zelić, ${ }^{a}$ V. Gilja, ${ }^{a}$ I. Grčićb i V. Tomašića ${ }^{a^{*}}$
}

a Zavod za reakcijsko inženjerstvo i katalizu, Fakultet kemijskog inženjerstva i tehnologije,

Sveučilište u Zagrebu, Marulićev trg 19, 10000 Zagreb

b Zavod za inženjerstvo okoliša, Geotehnički fakultet, Sveučilište u Zagrebu,

Hallerova aleja 7, 42000 Varaždin

\begin{abstract}
Sažetak
Velika ekonomska kriza koja se u posljednjem desetljeću osjeća u cijelom svijetu ponovno je potakla razmišljanja o potrebi "reindustrijalizacije". Reindustrijalizacija je ekonomski, društveni, ekološki i politički proces upravljanja nacionalnim resursima s ciljem revitalizacije industrije i ostalih gospodarskih aktivnosti, a oslanja se na razvoj i primjenu novih i inovativnih tehnologija. U okviru takvih nastojanja kemijsko inženjerstvo ima odlučujuću ulogu. Prema mišljenju mnogih znanstvenika reindustrijalizacija i razvoj "industrije za budućnost" temeljit će se na tri ključna područja: očuvanju i remedijaciji okoliša, uštedi energije i poticanju razvoja obnovljivih izvora energije te zaštiti ljudskog zdravlja. To nameće i potrebu prilagodbe sustava visokog obrazovanja novim industrijskim i ekonomskim izazovima.

U novije vrijeme sve se češće susrećemo s postignućima koja izlaze iz okvira "tradicionalnog" kemijskog inženjerstva, a uglavnom se zasnivaju na primjeni novog pristupa poznatog pod nazivom intenzifikacija procesa. Znanstvenici i inženjeri intenzivno rade na otkriću novih procesnih uređaja i tehnika, što predstavlja velik iskorak u odnosu na dosadašnja saznanja o kemijskim procesnim postrojenjima i omogućava razvoj integriranih, sigurnijih, energetski učinkovitijih i ekološki prihvatljivijih tehnologija. Zahvaljujući snažnom razvoju znanosti i sve većem interesu javnosti za to područje, intenzifikacija procesa postupno se počinje izdvajati kao nova disciplina unutar kemijskog inženjerstva.

Zbog opsežnosti problematike u ovom radu ilustrirani su primjeri naprednih izvedbi fotokatalitičkih reaktora razvijenih primjenom metodologije intenzifikacije procesa, uključujući fotokatalitičke reaktore s rotirajućim diskom/bubnjem, mikroreaktore, membranske reaktore (sa suspendiranim i imobiliziranim fotokatalizatorom), keramičke monolite s optičkim vlaknima te uobičajene izvedbe solarnih reaktora. Istraživanja u tom području predstavljaju velik izazov s obzirom na mogućnost primjene takvih sustava za rješavanje globalnih problema u zaštiti okoliša, primarno onih vezanih uz pročišćavanje voda, otpadnih voda, uključujući i uklanjanje postojanih organskih spojeva i patogenih mikroorganizama iz vodenih resursa.
\end{abstract}

\section{Ključne riječi}

Intenzifikacija procesa, fotokatalitički proces, obrada voda, napredni oksidacijski procesi, izvedbe reaktora

\section{Uvod}

Za uvođenje pojma intenzifikacija procesa (engl. process intensification, PI), koji se prvi put spominje 1970-ih, zaslužni su Kleemann i sur. te Ramshaw, a potaknut je potrebom za značajnim smanjenjem kapitalnih troškova industrijske proizvodnje. ${ }^{1,2}$ Ramshaw je 1995. godine tijekom otvaranja prvog međunarodnog kongresa o intenzifikaciji procesa u kemijskoj industriji definirao intenzifikaciju procesa kao novu strategiju koja podrazumijeva značajno smanjenje fizičke veličine kemijskog postrojenja uz istodobno postizanje željenih ciljeva proizvodnje. ${ }^{2} \mathrm{~S}$ vremenom su se pojavile i druge definicije koje se nisu zasnivale isključivo na smanjenju veličine postrojenja ili pojedinih procesnih uređaja, nego i na povećanju proizvodnih kapaciteta s obzirom na volumen procesnih uređaja, smanjenju potrošnje energije po toni produkta te značajnom smanjenju nastajanja otpada i/ili sporednih produkata. U skladu s takvim tumačenjima Stankiewicz i Moulijn pod intenzifikacijom procesa podrazumijevaju sve istraživačke aktivnosti u području kemijskog inženjerstva koje dovode do otkrića

*Autor za dopisivanje: Prof. dr. sc. Vesna Tomašić

Email: vtomas@fkit.hr i razvoja znatno manjih, čišćih, sigurnih, jeftinih, energetski učinkovitih i održivih tehnologija. ${ }^{3}$ Pristup poznat pod nazivom flow chemistry, koji je u novije vrijeme sve popularniji u farmaceutskoj industriji jer omogućava prelazak s kotlastih (šaržnih) na kontinuirane procese, a samim time bolju ekonomičnost i bolje vođenje procesa, također je primjer primjene metodologije intenzifikacije procesa. Treba napomenuti da se nove kemijske sinteze ili promjene u sastavu katalizatora ne razmatraju u okviru metodologije intenzifikacije procesa bez obzira na značajne promjene do kojih mogu dovesti u odnosu na postojeće tehnologije, uključujući i povećanje ukupne učinkovitosti procesa. Osnovna zamisao na kojoj se zasniva intenzifikacija procesa je integracija tokova mase i energije. Međutim, intenzifikacija procesa ne može se poistovjetiti s poboljšanjima koja su rezultat optimiranja ili integracije procesa. Isto tako, kod intenzifikacije procesa naglasak nije samo na racionalizaciji i poboljšanju ekonomičnosti procesa nego na razvoju održivih tehnologija utemeljenih na inovacijama i novim inženjerskim rješenjima. Zbog svega navedenog razumljivo je da kemijska industrija i znanstvenici pokazuju velik interes za tu problematiku. Kao što je shematski prikazano na slici 1 intenzifikacija procesa u širem smislu uključuje dva osnovna inženjerska pristupa: 
a) razvoj novih procesnih uređaja ili opreme (npr. napredne izvedbe reaktora i procesnih uređaja koji se razlikuju od tradicionalnih izvedbi, a omogućavaju intenzivno miješanje, prijenos topline i mase i sl.) te

b) razvoj novih procesnih metoda i/ili tehnika (npr. nove ili hibridne separacije, integracija reakcije i separacije, izmjena topline i faznog prijelaza u tzv. višenamjenskim reaktorima (reaktori s reverznim tokom, reaktivna destilacija, reaktivna ekstrakcija, membranski reaktori, gorive ćelije i sl.)), tehnike koje primjenjuju alternativne izvore energije (npr. Sunčeva energija, ultrazvuk, mikrovalovi, plazma tehnologija i sl.) te primjenu novih metoda vođenja i razvoja procesa (npr. namjerno izazvana nestacionarnost procesa). Nedvojbeno je da takav pristup koji se oslanja na primjenu metodologije intenzifikacije procesa omogućava značajan napredak u području (bio)kemijske proizvodnje i pretvorbe tvari. ${ }^{1-7}$

$\mathrm{U}$ radu je dan uvid u nekoliko naprednih izvedbi fotokatalitičkih reaktora nastalih kao rezultat primjene metodologije intenzifikacije procesa. Rad je nastavak ranijeg rada u kojem su analizirane osnovne značajke heterogene fotokatalize i uobičajene izvedbe fotoreaktora za pročišćavanje zraka. ${ }^{8}$ Cilj ovog rada je upoznavanje s naprednim izvedbama fotokatalitičkih reaktora za obradu voda i otpadnih voda koji pokazuju velike i još uvijek nedovoljno istražene mogućnosti za rješavanje globalnih problema u zaštiti okoliša. lako je osnovni princip rada pri heterogenoj fotokatalizi uglavnom neovisan o mediju na koji se primjenjuje (voda ili zrak), postoje i određene specifičnosti vezane uz primjenu fotoreaktora za obradu voda koje će u nastavku teksta biti posebno istaknute.

\section{Onečišćenje voda i otpadnih voda postojanim organskim spojevima}

Pojava postojanih organskih spojeva u izvorima pitkih voda, otpadnim vodama iz kemijske industrije i termoenergetskih postrojenja, procjednim vodama s odlagališta otpada ili s poljoprivrednih površina te u ostalim vodenim medijima izaziva sve veću zabrinutost javnosti. Prema podatcima Svjetske zdravstvene organizacije $(\mathrm{WHO})$ potrošnja vode potrebna za ispunjenje osnovnih životnih potreba iznosi između 50 i 100 litara vode dnevno po osobi. ${ }^{9,10}$ Ujedinjeni narodi (UN) u srpnju 2010. godine donijeli su Rezoluciju 64/292, prema kojoj je pristup pitkoj vodi i sanitaciji osnovno ljudsko pravo. ${ }^{11}$ Međutim, poražavajući podatci Vijeća Europske unije (EU) za 2019. godinu iznose činjenicu da više od trećine ljudi u svijetu u današnje vrijeme nema pristup zdravstveno ispravnoj, pitkoj vodi.

Zahvaljujući donošenju sve strožih zakonskih propisa i primjeni odgovarajućih tehničkih mjera i modernih tehnologija postignuto je značajno smanjenje ispuštanja onečišćivala u okoliš. U posljednja tri desetljeća istraživanja u području zaštite okoliša usmjerena su na prioritetnu skupinu onečišćivala u koju se ubrajaju postojani organski spojevi (engl. persistent organic pollutants, POP). Kao što sam naziv govori, u skupinu postojanih organskih spojeva ubrajaju se organski spojevi postojani/otporni na kemijsku, biološku i fotokatalitičku razgradnju. Zbog velike postojanosti može doći do njihove bioakumulacije u okolišu ili se mogu prenositi na velike udaljenosti i sudjelovati u prehrambenom lancu s dalekosežnim posljedicama na ljudsko zdravlje i stanje okoliša u cjelini. Dodatni problem odnosi se na kumulativni učinak brojnih postojanih organskih spojeva prisutnih u okolišu. Stockholmska konvencija, koja je prihvaćena u EU zakonodavstvu još 2004. godine, uključuje dvanaest najopasnijih spojeva ili skupina spojeva, kao što

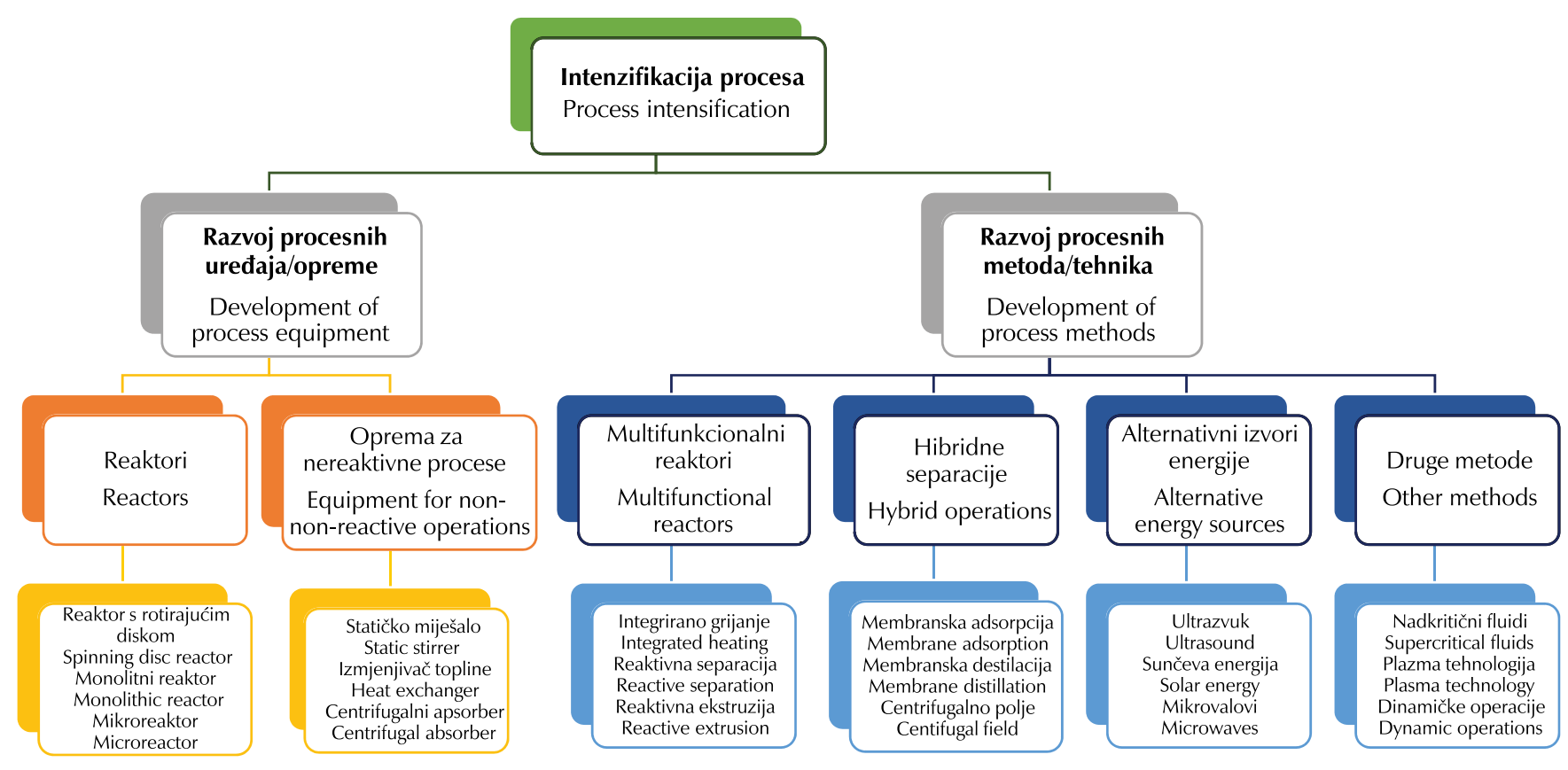

Slika 1 - Elementi intenzifikacije procesa i primjeri njihove upotrebe

Fig. 1 - Elements of process intensification with examples of usage 
su pesticidi, insekticidi, usporivači gorenja, industrijske i tehničke kemikalije (npr. poliklorirani bifenili te spojevi koji nastaju kao sporedni produkti spaljivanja i industrijskih procesa (npr. dioksini i furani)). ${ }^{12}$ Popis postojanih organskih spojeva koji se pojavljuju u okolišu neprestano se proširuje. U novije vrijeme sve istaknutiji problem pri zaštiti i obradi otpadnih voda odnosi se na organske ksenobiotike i njihove metabolite, tj. relativno novije spojeve za koje još uvijek nema dovoljno ekotoksikoloških podataka pomoću kojih bi se mogao procijeniti njihov utjecaj na zdravlje ljudi i kvalitetu vodenoga okoliša. Ksenobiotici su sintetički kemijski spojevi, a uključuju policikličke aromatske ugljikovodike, halogenirane aromatske i alifatske spojeve, farmaceutike, površinski aktivne tvari i njihove metabolite, azo-spojeve i slične spojeve s nepoželjnim učinkom na okoliš. U širem smislu, ksenobiotici obuhvaćaju i spojeve koji su prirodno prisutni u biosferi (npr. naftne ugljikovodike, hormone i sl. spojeve) čije su koncentracije u okolišu znatno veće od očekivanih zbog aktivnosti ljudi i industrijske djelatnosti. ${ }^{13} \mathrm{U}$ industrijskim centrima ksenobiotici prisutni u otpadnim vodama povezuju se s proizvodnim procesima, dok je njihova prisutnost u komunalnim vodama rezultat različitih primjena u kućanstvima (npr. sredstva osobne higijene, kozmetika i detergenti sadrže različite ksenobiotike, kao što su surfaktanti, biocidi, ulja, mirisi i sl.). Farmaceutici (analgetici, antibiotici i dr.) i steroidni hormoni sljedeća su kategorija ksenobiotika koji potječu iz kućanstava, a sve češće su prisutni u podzemnim vodama koje služe kao potencijalni izvori pitkih voda. S obzirom na to da su mnogi ksenobiotici vrlo toksični, potrebno ih je ukloniti iz okoliša primjenom odgovarajućih tehnologija. Kao posebno obećavajuća tehnologija pokazala se fotokataliza.

Za uklanjanje ksenobiotika iz otpadnih voda primjenjuju se različite kemijske, fizikalne i biološke metode. Uobičajene kemijske i fizikalne metode uključuju: a) adsorpciju na aktivnom ugljenu ili nekom drugom adsorbensu, b) kemijsku oksidaciju (katalitičku oksidaciju, fotokatalizu, Fentonovu reakciju, ozoniranje i sl.), c) membransku filtraciju te d) spaljivanje. Spomenute metode u nekim slučajevima mogu biti vrlo učinkovite, međutim nisu uvijek dovoljno uspješne u postizanju sve strožih kriterija u zaštiti okoliša. Kod nekih od spomenutih metoda ne mijenja se kemijska struktura nepoželjnog spoja, nego samo dolazi do njegova koncentriranja i prijenosa iz jedne u drugu fazu (npr. na odgovarajući adsorbens). To može biti dobro kratkoročno rješenje pri obradi voda, međutim dugoročno se ne rješava potencijalan rizik vezan uz prisutnost neželjenog spoja (npr. u adsorbensu koji treba zbrinuti na odgovarajući način prije odlaganja u okoliš). Tehnologijama koje se zasnivaju na kemijskoj oksidaciji i spaljivanju dolazi do razgradnje i trajnog uklanjanja neželjenog onečišćivala iz okoliša. Međutim, te tehnologije su energetski zahtjevne i skupe, a mogu dovesti i do nastajanja novih toksičnih spojeva. Postoje i druga ograničenja koja utječu na izbor odgovarajuće tehnologije. Naprednije tehnologije obrade otpadnih voda, kao što su katalitička i fotokatalitička oksidacija te kemijska precipitacija ili taloženje uglavnom se primjenjuju za uklanjanje spojeva štetnih za okoliš koji su u prethodnim stupnjevima obrade već djelomično uklonjeni nekom od dostupnih konvencionalnih metoda (to se uglavnom odnosi na biorazgradljive organske spojeve, suspendirane krutine, koloidne supstancije, spojeve fosfora i dušika, teške metale, mikroorganizme i sl.). Biološki procesi su jeftiniji od kemijskih i fizikalnih procesa, međutim primjenjuju se za uklanjanje lako razgradljivih spojeva i općenito kao izdvojeni postupci nisu prikladni za uklanjanje ksenobiotika. Očigledno je da izbor prihvatljivog rješenja za smanjenje opterećenja otpadnih voda predstavlja prioritet u kontekstu očuvanja vodnih ekosustava sukladno načelima održivog razvoja. ${ }^{14} U$ nastavku teksta detaljnije će biti opisani napredni oksidacijski procesi koji omogućavaju rješavanje najsloženijih problema u pročišćavanju otpadnih voda s ciljem zaštite okoliša.

\section{Napredni oksidacijski procesi}

U posljednja tri desetljeća povećao se broj istraživanja usmjerenih na razvoj naprednih oksidacijskih procesa (engl. advanced oxidation processes, AOPs). ${ }^{15,16}$ Napredni oksidacijski procesi uglavnom se zasnivaju na generiranju jako reaktivnih hidroksilnih radikala $\left({ }^{\circ} \mathrm{OH}\right)$ i ostalih reaktivnih radikala i ionskih vrsta in situ koje u reakcijskom mediju nastaju različitim mehanizmima ovisno o osnovnoj izvedbi i načinu provođenja procesa. Ovisno o broju prisutnih faza dijele se na homogene i heterogene procese. Heterogeni procesi uključuju primjenu katalizatora, pri čemu heterogenost proizlazi iz činjenice da je onečišćenje prisutno u vodenoj fazi, dok je fotokatalizator kruta faza. ${ }^{17}$ Treba naglasiti da primjenljivost AOP-a, osim o toksičnosti spoja koji se želi ukloniti i dostupnosti odgovarajuće metode generiranja ${ }^{\bullet} \mathrm{OH}$, u velikoj mjeri ovisi i o stupnju onečišćenja otpadne vode. ${ }^{18}$ Osobito su prikladni za uklanjanje specifičnih organskih spojeva, kao što su halogenirani ugljikovodici, aromati, pentaklorfenol, nitrofenol, spojevi iz skupine detergenata, bojila, pesticida, farmaceutika i drugih za okoliš potencijalno opasnih spojeva. ${ }^{15}$

Napredni oksidacijski procesi koji se zasnivaju na primjeni poluvodičke fotokatalize pokazuju velike potencijale za praktičnu primjenu pri obradi voda, kako za dezinfekciju i pročišćavanje pitkih voda, obradu industrijskih i otpadnih voda tako i za remedijaciju podzemnih voda in situ. Osim primjene u zaštiti okoliša, fotokataliza je napredna tehnologija koja se sve više primjenjuje i u ostalim područjima ljudske djelatnosti, od naprednih kemijskih sinteza do proizvodnje energije i medicine. Brojni materijali, kao što su $\mathrm{TiO}_{2}, \mathrm{ZnO}, \mathrm{ZrO}_{2}, \mathrm{Fe}_{2} \mathrm{O}_{3}, \mathrm{WO}_{3}, \mathrm{BiVO}_{4}$ i dr. izučavani su kao potencijalni fotokatalizatori za razgradnju različitih organskih spojeva prisutnih u vodenim medijima. ${ }^{19,20}$ Međutim, $\mathrm{TiO}_{2}$ (Degussa/Evonik P25) pokazao se izuzetno dobrim fotokatalizatorom, zbog velike fotokatalitičke aktivnosti i fotostabilnosti, kemijske i biološke inertnosti kao i zbog povoljne cijene. Prednosti poluvodičke fotokatalize u usporedbi s drugim oksidacijskim procesima očituju se u sljedećem: a) zasniva se na primjeni niskoenergetskog ultraljubičastog zračenja za pobudu/aktivaciju fotokatalizatora, b) omogućava potpunu mineralizaciju brojnih organskih spojeva, uključujući i spojeve s ograničenom biorazgradljivošću, c) za razliku od mnogih katalitičkih procesa kod kojih je za uspješno provođenje reakcije potrebno raditi pri povišenim temperaturama i tlakovima, fotokatalitički procesi provode se pri blagim uvjetima, uglavnom pri sobnoj temperaturi i atmosferskom tlaku. 
Usprkos brojnim prednostima, fotokataliza još uvijek nema širu komercijalnu primjenu za remedijaciju okoliša. Zbog toga su novija istraživanja u tom području usmjerena na ključne inženjerske aspekte o kojima ovisi primjenjivost takvih sustava u realnim uvjetima. To se odnosi na određivanje zavisnosti brzine fotokatalitičke reakcije o procesnim varijablama i parametrima, a posebice na detaljno izučavanje: načina kontakata između sudionika reakcije, procesa prijenosa, hidrodinamike te odgovarajućih izvedbi fotoreaktora o kojima također ovisi učinkovitost takvih sustava. Osim samog izbora i izvedbe fotoreaktora, za komercijalizaciju takvih sustava od velike važnosti je modeliranje fotokatalitičkih reaktora koje je vrlo složen zadatak. Dodatni izazov tijekom istraživanja je raspršenje i apsorpcija fotona na površini fotokatalizatora, složenost mehanizama fotoreakcija i drugi čimbenici čiji je utjecaj potrebno sagledati prilikom razvoja matematičkog modela, dimenzioniranja reaktora i uvećanja procesa.

Kinetika heterogene fotokatalitičke reakcije i zavisnost brzine reakcije o procesnim varijablama i parametrima detaljno je opisana ranije u preglednom radu, $^{8}$ stoga će $u$ nastavku teksta naglasak biti dan na intenzifikaciju heterogenih fotokatalitičkih procesa za uklanjanje onečišćivala iz otpadnih voda. Općenito, brzina fotokatalitičke reakcije ovisi o: prirodi onečišćivala (struktura i veličina molekule, broj i položaj funkcionalnih skupina, topljivost, toksičnost), koncentraciji onečišćivala, prirodi medija na koji se primjenjuje (voda, zrak), koncentraciji kisika, pH medija, temperaturi, fizičko-kemijskim značajkama fotokatalizatora, načinu kontakta između sudionika fotoreakcije, izvoru zračenja (snaga, intenzitet, valna duljina) i dr. ${ }^{21-23}$ Poznato je da samo 4 - $5 \%$ prirodnog Sunčeva zračenja posjeduje energiju dovoljnu za aktivaciju fotokatalizatora $\left(\mathrm{TiO}_{2}\right)$, ako se ne provede odgovarajuća modifikacija koja omogućava aktivaciju u vidljivom dijelu spektra Sunčeva zračenja. Nažalost, dio svjetlosne energije može se izgubiti zbog raspršenja zračenja odnosno načina prolaska zračenja kroz reakcijski medij. Problemi vezani uz nedovoljnu učinkovitost heterogenih fotokatalitičkih procesa mogu se značajno ublažiti ili ukloniti primjenom odgovarajućih inženjerskih rješenja koja, među ostalim, proizlaze iz primjene metodologije intenzifikacije procesa. Inženjerski aspekti koje posebno treba razmotriti uključuju: izbor odgovarajuće izvedbe fotoreaktora, način smještaja fotokatalizatora unutar reaktora (vodeći pri tome računa o raspršenju i apsorpciji fotona na površini fotokatalizatora i o potrebi za separacijom katalizatora nakon provedene reakcije) te način kontaktiranja između ključnih sudionika sustava. Posebno je važno detaljno sagledati sljedeće čimbenike vezane uz dizajniranje takvih naprednih sustava $\mathrm{i}$ njihovu potencijalnu primjenu u praksi: a) osigurati učinkovitu aktivaciju/pobudu fotokatalizatora primjenom odgovarajućeg niskoenergetskog izvora zračenja, b) osigurati dovoljno veliku aktivnu površinu fotokatalizatora u odnosu na ukupni volumen fotoreaktora odnosno vodenog medija s kojim je u kontaktu, c) postići učinkovito miješanje/strujanje u reaktoru ovisno o njegovoj izvedbi i uvjetima provedbe procesa pri kojima neće doći do ograničenja brzine zbog fizičkih procesa prijenosa tvari, d) omogućiti obradu velikih volumena onečišćenih voda u realnim sustavima te e) osigurati ekonomičnost i fleksibilnost rada u širokom području radnih uvjeta.

\section{Osnovne izvedbe fotoreaktora za obradu voda}

Postoje različite izvedbe reaktora koje se mogu primijeniti za provedbu fotokatalitičkih reakcija u kapljevitoj fazi. Izbor odgovarajuće izvedbe uglavnom ovisi o uvjetima provedbe procesa te o području primjene odnosno onečišćenju koje je potrebno ukloniti (od pesticida, herbicida i drugih spojeva potencijalno štetnih za okoliš do patogena, virusa, bakterija i sl.). Općenito, ovisno o osnovnim izvedbenim značajkama fotoreaktori za obradu voda mogu se podijeliti u tri karakteristične skupine s obzirom na: ${ }^{24}$

- položaj fotokatalizatora unutar reaktora (suspenzijski i imobilizirani),

- položaj izvora zračenja u odnosu na reaktor (izvori zračenja smješteni unutar i izvan reaktora ili prijenos zračenja pomoću optičkog uređaja),

- izvor zračenja (UV ili Sunčevo zračenje).

Pojednostavljen prikaz različitih izvedbi fotoreaktora dan je na slici 2.

\subsection{Suspenzijski fotoreaktori}

Fotoreaktori sa suspendiranim slojem katalizatora ili suspenzijski fotoreaktori najčešće su istraživani fotoreaktori za obradu voda, a uglavnom se primjenjuju u laboratorijima u početnim fazama istraživanja. Taj tip reaktora pokazuje veću učinkovitost $\mathrm{u}$ odnosu na reaktore $\mathrm{s}$ imobiliziranim slojem katalizatora zbog veće dostupnosti aktivnih centara fotokatalizatora molekulama reaktanata. ${ }^{23}$ Konstanta brzine razgradnje u solarnom suspenzijskom fotoreaktoru može biti dva do pet puta veća od konstante brzine razgradnje na imobiliziranom sloju fotokatalizatora. ${ }^{25}$ Međutim, prilikom usporedbe tih osnovnih izvedbi treba voditi računa i o drugim čimbenicima. Posebno važnu ulogu ima udio apsorbiranog zračenja koji je u suspenzijskim fotoreaktorima znatno manji zbog većeg raspršenja zračenja. Dodatni problem pri radu sa suspenzijskim fotoreaktorima odnosi se na separaciju čestica $\mathrm{TiO}_{2}$ iz vodene suspenzije nakon provedene fotoreakcije, koje mogu biti reda veličine $0,1 \mu \mathrm{m}$. Nanočestice $\mathrm{TiO}_{2}$ koje se ponekad primjenjuju u suspenzijskim fotoreaktorima često su modificirane teškim i plemenitim metalima, koji mogu dodatno ugroziti okoliš ako se separacija ne provede na zadovoljavajući način. Potreba naknadne separacije fotokatalizatora čini proces složenijim i dovodi u pitanje ekonomsku isplativost procesa. Separacija se obično provodi tehnikama ultracentrifugiranja, taloženja, koagulacije (npr. s $\mathrm{AlCl}_{3}$ ) te ultrafiltracije. Potencijalno rješenje za separaciju fotokatalizatora iz reakcijskog medija uključuje primjenu fotokatalitičkog membranskog reaktora, koji pruža i dodatne prednosti kao što su mogućnost kontinuirane provedbe procesa te rad pri različitim vremenima zadržavanja molekula onečišćivala unutar reaktora. ${ }^{26}$ Fotokatalitički membranski reaktori su hibridni reaktori u kojima je intenzifikacija procesa ostvarena povezivanjem fotokatalize s membranskim separacijskim procesom. ${ }^{27,28}$ 


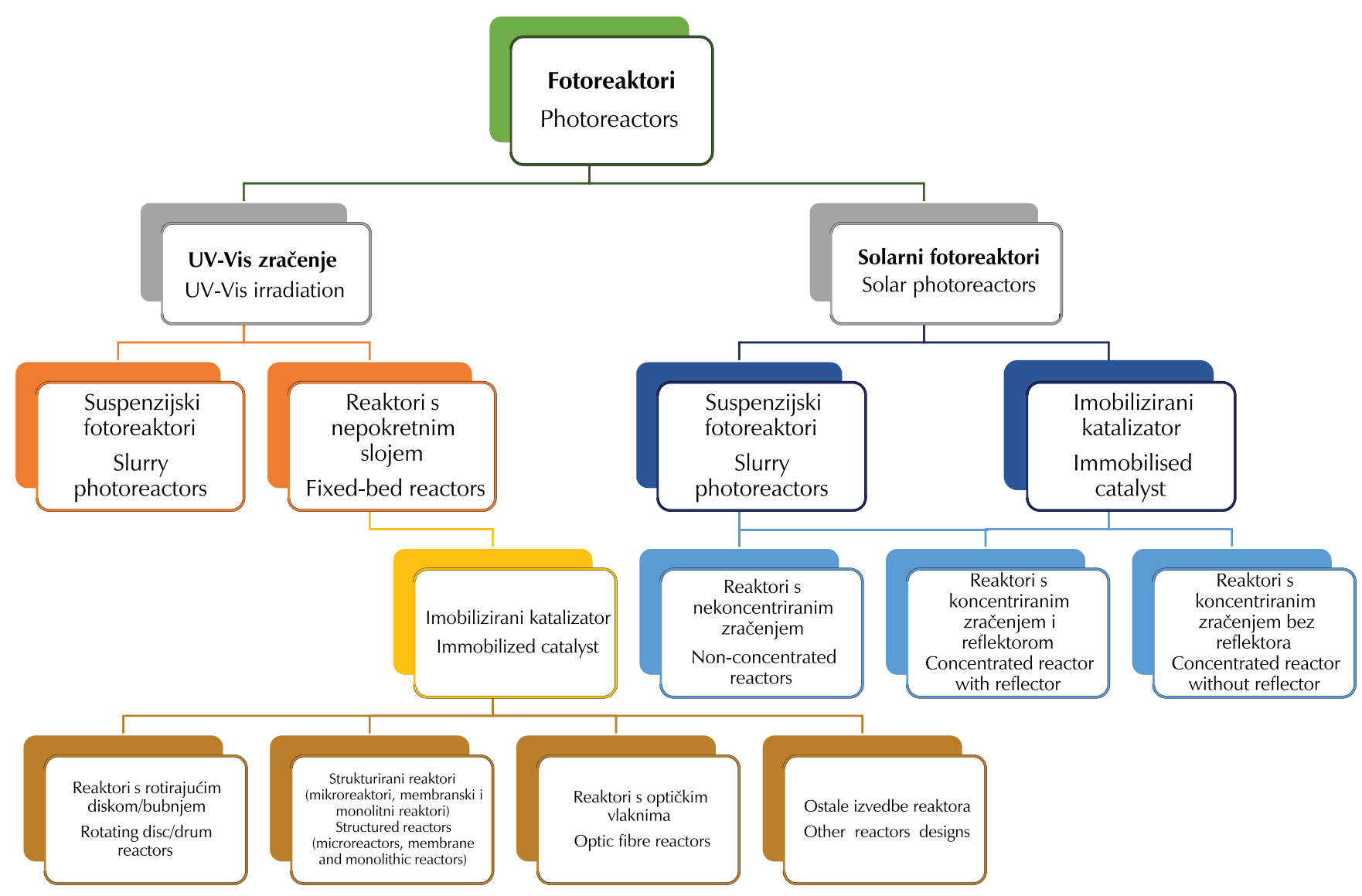

Slika 2 - Potencijalna podjela fotokatalitičkih reaktora

Fig. 2 - Potential classification of photocatalytic reactors

\subsection{Fotoreaktori s nepokretnim/imobiliziranim slojem}

Fotoreaktori s imobiliziranim slojem katalizatora imaju velike mogućnosti primjene, kako za obradu voda tako i za pročišćavanje zraka. Ta izvedba uključuje reaktore kod kojih se fotokatalizator nanosi na odgovarajući nosač, najčešće u obliku tankog filma, zahvaljujući djelovanju fizičkih površinskih sila ili kemijskih veza. U jednostavnijim izvedbama fotoreaktora s imobiliziranim slojem fotokatalizator se nanosi na stijenke reaktora neposredno uz izvor zračenja ili se nanosi na odgovarajući nosač fotokatalitičkog sloja. Ključna prednost tih reaktora koji se ubrajaju u protočne tipove fotoreaktora te omogućavaju kontinuirani način rada nalazi se $u$ jednostavnosti izvedbe te $u$ odsutnosti potrebe za separacijom fotokatalizatora iz reakcijske smjese. Kao uobičajeni nosači upotrebljavaju se: aktivirani ugljen, ${ }^{29}$ optička vlakna, ${ }^{30,31}$ staklo, ${ }^{32}$ staklene granule, ${ }^{33}$ staklena vuna, ${ }^{32}$ membrane, ${ }^{34}$ kvarcni pijesak, ${ }^{35}$ zeoliti, $^{29}$ teflon $^{36-38}$ i sl. Važan preduvjet za uspješan rad fotoreaktora s imobiliziranim slojem katalizatora je način strujanja i visok stupanj interakcije između radnog medija u kojem se nalaze onečišćenja koja je potrebno razgraditi i fotokatalitičkog sloja. Nedostatci fotoreaktora s imobiliziranim slojem su: a) mala specifična površina fotokatalizatora u odnosu na ukupni volumen reaktora, b) problemi vezani uz manje iskorištenje zračenja zbog raspršenja zračenja u dodiru s imobiliziranim slojem fotokatalizatora, c) ograničenja vezana uz otpor prijenosu tvari među- i unutarfaznom difuzijom te d) mogućnost deaktivacije fotokatalizatora, nedovoljne mehaničke stabilnosti zbog ispiranja fotokatalitičkog sloja te otežana regeneracija fotokatalizatora in situ. Prednosti uglavnom dominiraju u odnosu na nedostatke fotoreaktora s nepokretnim/imobiliziranim slojem u usporedbi s odgovarajućim izvedbama suspenzijskih fotoreaktora.

\subsection{Fotoreaktori s obzirom na položaj izvora zračenja i vrstu zračenja}

U literaturi se spominje velik broj reaktora koji se mogu podijeliti na različite načine, primjerice s obzirom na smještaj izvora zračenja u odnosu na reaktor. Da bi se postigla što bolja učinkovitost, fotoreaktori moraju ostvariti velik omjer aktivnog imobiliziranog sloja fotokatalizatora i pobuđene aktivne površine te veliku gustoću aktivnih centara na površini fotokatalizatora koji su u kontaktu s jednim ili više reaktanata. ${ }^{39} \mathrm{~S}$ obzirom na položaj izvora zračenja moguće su tri izvedbe fotoreaktora, pa tako izvor zračenja može biti smješten izvan ili unutar reaktora, a homogena raspodjela zračenja unutar reaktora može se postići i primjenom pomoćnih uređaja. ${ }^{40}$ Prilikom fotokatalitičkog procesa mogu se primijeniti dvije vrste zračenja: a) alternativni oblici umjetnog UV-Vis zračenja uz uporabu komercijalno dostupnih lampi, svjetlećih dioda, optičkih vlakana i drugih izvora za simulaciju Sunčeva zračenja) ${ }^{41-63}$ te b) pri- 
rodno Sunčevo zračenje. Generiranje fotona koje je nužno za aktivaciju fotokatalizatora najvažniji je izvor troškova tijekom fotokatalitičke obrade otpadnih voda. Upravo zbog toga se nastoji iskoristiti Sunčeva energija kao ekološki i ekonomski prihvatljiviji oblik aktivacije fotokatalizatora. Velik napredak u području nanotehnologije i sinteze nanomaterijala s ciljem primjene prirodne Sunčeve energije snažno su ubrzali razvoj u tom području, posebice u toplijim krajevima svijeta koji obiluju tim oblikom energije. $U$ tom kontekstu pozornost brojnih istraživača usmjerena je na poboljšanje učinkovitost fotokatalitičkih sustava primjenom metodologije intenzifikacije fotokatalitičkih procesa. U fotokatalitičkim sustavima to se može postići na dva osnovna načina: a) poboljšanjem aktivnosti postojećih fotokatalizatora i razvojem novih fotokatalizatora s velikom aktivnošću u vidljivom području spektra Sunčeva zračenja, pri čemu je intenzifikacija procesa usmjerena na primjenu Sunčeva zračenja kao alternativnog izvora energije te b) razvojem naprednih izvedbi fotokatalitičkih sustava, što se postiže integracijom uobičajenih fotokatalitičkih sustava s odgovarajućim fizičkim, kemijskim i biološkim sustavima te uklanjanjem ograničenja vezanih uz prijenos fotona (što je također vezano uz poboljšanje učinkovitosti aktivacije fotokatalizatora) kao i ograničenja vezanih uz procese prijenosa tvari koji su rezultat primjene odgovarajućeg fotokatalitičkog sustava.

$\mathrm{Uz} \mathrm{TiO}_{2}$, koji je uobičajeni predstavnik metalnih poluvodičkih materijala i najviše izučavan fotokatalizator, sve se više primjenjuju i nemetalni poluvodički materijali, među kojima se posebice ističe grafitni ugljikov nitrid $\left(\mathrm{g}-\mathrm{C}_{3} \mathrm{~N}_{4}\right)$. Grafitni ugljikov nitrid $\left(g-\mathrm{C}_{3} \mathrm{~N}_{4}\right.$ ) ima poželjna svojstva koja bi trebao imati fotokatalitički materijal (niska cijena, jednostavan proces priprave, prihvatljiva stabilnost i aktivnost u vidljivom dijelu spektra), te ga neki istraživači, uz dobro poznati $\mathrm{TiO}_{2} \mathrm{P} 25$, smatraju novim standardom u fotokatalizi. ${ }^{64}$ Poznato je da postoje velike mogućnosti poboljšanja svojstava postojećih fotokatalizatora, uglavnom poluvodičkih materijala kao što su: $\mathrm{TiO}_{2}, \mathrm{ZnO}, \mathrm{ZnS}, \mathrm{Fe}_{2} \mathrm{O}_{3}, \mathrm{SrTiO}_{3}$ i dr. ${ }^{65}$ To je moguće postići primjenom naprednih ili tzv. zelenih metoda pripreme fotokatalizatora, npr. mehanokemijske sinteze, sintezama potpomognutim mikrovalovima i sl. te optimiranjem parametara pripreme, modificiranjem sastava i površine fotokatalizatora dodatnim postupcima. ${ }^{66}$

\section{Napredne izvedbe fotokatalitičkih reaktora - primjena metodologije intenzifikacije procesa}

Primjena metodologije intenzifikacije procesa rezultirala je razvojem brojnih naprednih izvedbi fotoreaktora kao što su fotokatalitički reaktori s rotirajućim diskom ili rotirajućim bubnjem, strukturirani fotokatalitički reaktori, npr. fotokatalitički mikroreaktori, membranski reaktori (s imobiliziranim ili suspendiranim slojem fotokatalizatora), monolitni reaktori te različitim izvedbama solarnih fotokatalitičkih reaktora u kojima se kao izvor pobude najčešće rabi prirodno Sunčevo zračenje. ${ }^{67} \mathrm{U}$ nastavku rada opisani su odabrani primjeri naprednih izvedbi fotokatalitičkih reaktora koji su nastali primjenom metodologije intenzifikacije procesa.

\subsection{Fotokatalitički reaktori s rotirajućim diskom/bubnjem}

Primjena različitih oblika rotacije unutar osnovne izvedbe fotokatalitičkog reaktora motivirana je nastojanjem da se intenzivira kontakt onečišćujućih tvari s površinom fotokatalitičkog sloja, uz istodobno povećanje brzine međufaznog prijenosa tvari u takvom fotokatalitičkom sustavu. Takvom izvedbom koja omogućava periodičku aktivaciju fotokatalitičkog sloja nastoji se povećati i fotoučinkovitost, tj. smanjiti brzina nastajanja neželjenih sporednih produkata. Postoje različite izvedbe reaktora s rotirajućim diskom/bubnjem: a) reaktor s jednim rotirajućim diskom s obzirom na os rotacije iznad kojeg se nalazi odgovarajući izvor zračenja (kao što je prikazano na slici 3), b) reaktor s više diskova usporedno spojenih na zajedničku os rotacije, pri čemu se odgovarajući izvori zračenja smještaju između pripadajućih diskova spojenih u seriju te c) reaktori s rotirajućim bubnjem, pri čemu vanjska površina bubnja izložena odgovarajućem izvoru zračenja može biti ravna odnosno bez dodatnih nabora ili može dolaziti s različitim profilima valovitosti da se dodatno poveća ukupna vanjska površina bubnja koja služi kao nosač fotokatalitičkog sloja.

Reaktor s rotirajućim diskom (engl. rotating or spinning disc reactor) prikazan je na slici 3. Osnovna značajka takve izvedbe je nastajanje tankog sloja kapljevine na površini diska, koji služi kao nosač fotokatalitičkog sloja. S obzirom na malu debljinu fotokatalitičkog sloja izbjegnut je otpor prijenosu tvari unutarfaznom difuzijom. Rotacijom nastale centrifugalne sile ravnomjerno raspršuju reakcijsku smjesu po cijeloj površini diska, što dovodi do nastajanja vrlo tankog sloja fluida/reakcijske smjese na površini diska. Na taj način postiže se velika brzina međufaznog prijenosa tvari $\mathrm{i}$ topline u sustavu te bolji prodor UV zračenja do površine diska. ${ }^{68}$ Debljina nastalog sloja kapljevine na površini diska ovisi o brzini rotacije te promjeru samog diska. ${ }^{69}$ Uvećanje tog procesa (engl. scale up) ne predstavlja velik problem,

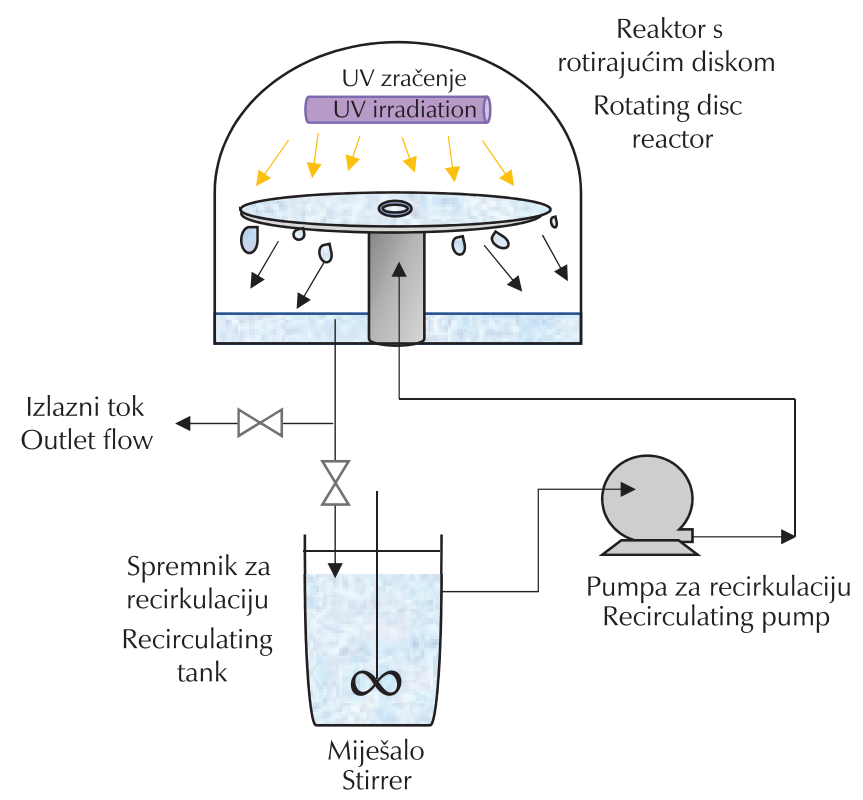

Slika 3 - Fotokatalitički reaktor s rotirajućim diskom

Fig. 3 - Photocatalytic rotating disc reactor 
budući da se jednostavno može postići povećanjem promjera diska ili instalacijom većeg broja diskova.

Ovisno o fizičkim svojstvima reakcijske smjese, volumnom protoku reakcijske smjese i brzini rotacije na površini rotirajućeg diska mogući su različiti profili strujanja koji mogu biti linearni, koncentrični, spiralni i nepravilni. ${ }^{70}$ Provedena su istraživanja kojima se nastojalo ispitati dolazi li na površini rotirajućeg diska do laminarnog ili turbulentnog toka. Boiarkina $i$ sur. ${ }^{71}$ eksperimentalno su potvrdili nastajanje nekoliko karakterističnih područja protoka. Prvo područje, koje se odnosi na područje ubrizgavanja trasera (boje), predstavlja područje u kojem reakcijska smjesa djelovanjem centrifugalnih sila ubrzava do brzine kojom se okreće rotacijski disk. Potom, u sljedećem području dolazi do turbulentnog toka reakcijske smjese, a u posljednjem području, s približavanjem reakcijske smjese rubu diska, dolazi do pojave laminarnog toka. ${ }^{71} \mathrm{~S}$ obzirom na osnovnu izvedbu razlikuju se horizontalni i vertikalni centrifugalni fotoreaktori. U prvom slučaju reakcijska smjesa uvodi se u središnji dio diska preko kojeg se zatim ravnomjerno raspršuje prema rubovima. U slučaju vertikalno postavljenih diskova povezanih preko centralne osi rotacije donje polovice diskova periodički su djelomično uronjene u reakcijsku smjesu, dok su neuronjeni dijelovi diskova izloženi UV zračenju. lako je teško izvesti zaključak o učinkovitosti takvih izvedbi na temelju objavljenih rezultata istraživanja, pretpostavlja se veća učinkovitost horizontalnog centrifugalnog fotoreaktora zbog boljeg iskorištenja intenziteta zračenja. ${ }^{72}$ Primjena fotoreaktora s rotirajućim diskom opisana je u manjem broju radova, a karakteristični primjeri primjene takvih sustava odnose se na fotokatalitičku razgradnju 4-klorofenola, metilenskog modrila, dehidroabetne kiseline, pesticida i $\mathrm{dr}^{73-75}$ Fotoreaktori s rotirajućim bubnjem (engl. rotating drum photoreactor) imaju dosta sličnosti s prethodno opisanom izvedbom reaktora. U takvim sustavima posebna pozornost posvećena je istraživanju utjecaja različitih profila valovitosti na površini bubnja s ciljem maksimalnog povećanja površine za imobilizaciju fotokatalitičkog sloja, iskorištenja potencijala za primjenu reflektirane svjetlosti te poboljšanja međufaznog prijenosa tvari do aktivnih centara. ${ }^{76,77}$

\subsection{Fotokatalitički mikroreaktori}

U novije vrijeme za provođenje fotokemijskih i fotokatalitičkih reakcija počeli su se primjenjivati fotokatalitički mikroreaktori. Njihova glavna prednost očituje se u velikom omjeru površine i volumena, što omogućuje učinkovito osvjetljenje kod fotokemijskih reakcija, a kod fotokatalitičkih reakcija učinkovito izlaganje katalizatora zračenju te maksimalan kontakt reaktanata s katalizatorom. Uslijed malih dimenzija kanala dolazi do brzog prijenosa tvari i topline te do pojave laminarnog strujanja. Kao izvor zračenja mogu se upotrijebiti i UV-LED diode, čime se dodatno pridonosi smanjenju karakterističnih dimenzija i poboljšanju učinkovitosti fotokatalitičkog sustava. Navedene prednosti mikroreaktora potvrđene su u brojnim istraživanjima. $U$ usporedbi s konvencionalnim izvedbama fotoreaktora velikih dimenzija primjenom mikroreaktora može se postići čak 11 puta veća masa katalizatora po jedinici volumena. Glavni nedostatak takve izvedbe je relativno mali protok kroz reakcijski sustav.
Keramika, polimeri, nehrđajući čelik i silikon neki su od materijala od kojih mogu biti izrađena kućišta mikroreaktora. Općenito se razlikuju dvije izvedbe mikrofotoreaktora: mikroreaktori s čipom te mikrokapilarni reaktori. Mikroreaktore s čipom karakterizira jednostavno upravljanje reakcijskom smjesom te integracija više procesnih jedinica. Izvedba čeličnih mikroreaktora može biti različita, od jednostavne koja se sastoji od mikromiješala u obliku slova T i uskih kanalića, do komercijalnih oblika s mikro proizvedenim komponentama. ${ }^{78}$

Unatoč učestaloj primjeni u organskoj kemiji, u literaturi je moguće pronaći tek nekoliko izdvojenih primjera primjene mikroreaktora za provođenje fotokemijskih reakcija, koji uključuju sintezu benzopinakola, proizvodnju singletnog kisika te fotokemijsko kloriranje alkilaromata. ${ }^{72,79,80}$ Učinkovitost mikroreaktora u fotokatalitičkom sustavu ispitana je primjenom razgradnje 4-klorofenola kao modelne komponente. Za tu svrhu primijenjen je keramički mikroreaktor čiji je pokrovni dio impregniran s $\mathrm{TiO}_{2}$ kao fotokatalitički aktivnom komponentom bio izrađen od transparentnog stakla, a kao izvor pobude upotrijebljen je UV-A LED. U takvom sustavu izbjegnuto je nastajanje 4-klorokatehola, hidrokinona i benzokinona kao glavnih sporednih produkata razgradnje 4-klorofenola. Zaključeno je da porastom protoka, odnosno smanjenjem vremena zadržavanja reakcijske smjese u kanalima mikroreaktora dolazi do smanjene brzine razgradnje onečišćenja. ${ }^{79}$

\subsection{Fotokatalitički membranski reaktori}

Fotokatalitički membranski reaktori (engl. photocatalytic membrane reactors, FMR) višenamjenski su reaktori koji povezuju katalitičku reakciju i membranski separacijski proces ${ }^{81}$ Primjenu nalaze u obradi voda onečišćenih raznim organskim onečišćujućim tvarima, poput natrijeva dodecil benzen sulfonata, bojila, herbicida i fenola. Važno je napomenuti da se osim za obradu onečišćenih voda primjenjuju i u plinovitim sustavima u kojima osiguravaju uspješnu oksidaciju metanola, etanola, fenola, trikloretilena i alkana (metan, etan i n-heptan). Osim njihove primjene u obradi vode i zraka, raste interes za njihovom primjenom u biotehnološkim sustavima, u kemijskoj te petrokemijskoj industriji, pri remedijaciji okoliša te u energetskom sektoru. ${ }^{82-84} \cup$ takvim integriranim sustavima membrana ne služi samo za separaciju već je sastavni dio reaktora - aktivno sudjeluje u kemijskim reakcijama povećavajući brzinu same reakcije, selektivnost i konverziju. Postoje različite izvedbe membrana, a kao primjer mogu se izdvojiti membrane anorganskog tipa, koje mogu imati različitu poroznost, a također mogu biti inertne ili katalitički aktivne. Razvoj membranskih reaktora u industrijskom mjerilu otežava nekoliko čimbenika: tip i očekivane značajke membrane, izbor odgovarajućeg nosača te procesna oprema nužna za osiguranje optimalnih procesnih uvjeta, potrebne stabilnost sustava i sl. ${ }^{85}$

Fotokatalitički membranski reaktori su hibridni reaktori u kojima se provode fotokatalitički i membranski procesi. U FMR-u fotokatalizator može biti suspendiran u otopini, nanesen na membranu ili može biti sastavni dio membrane. Uloga membrane je separacija čestica fotokatalizatora ili 
služi kao selektivna barijera za određena onečišćivala. ${ }^{86,87}$ Tri su moguće kombinacije membrana i fotokatalizatora: a) imobilizirani fotokatalitički sloj na površini inertne membrane, b) fotokatalizator unutar porozne strukture membrane i c) katalizator ili kao sastavni dio membrane - "prava" fotokatalitička membrana.

Velika pozornost usmjerena je na izbor membrane koja treba biti otporna na UV zračenje i hidroksilne radikale koji se stvaraju u sustavu. S obzirom na morfološka svojstva razlikuju se porozne, neporozne, simetrične te asimetrične membrane. $U$ fotokatalizi se, unatoč visokoj cijeni, zahvaljujući dobrim kemijskim i termičkim značajkama obično primjenjuju polimerne membrane. $U$ brojnim radovima opisana je primjena poliviniliden fluoridnih (PVDF) membrana. Razgradnja fulvinske kiseline i bisfenola A primjeri su reakcija u kojima PVDF membrana pronalazi svoju primjenu. ${ }^{88,89}$ Unatoč dobrim mehaničkim značajkama te dobroj termičkoj i hidrolitičkoj stabilnosti, očigledan nedostatak pri njihovoj primjeni u obradi voda jest često propadanje membrane te smanjenje njezine propusnosti. Razlog tome je hidrofobni karakter organskih onečišćujućih tvari zbog kojeg imaju kemijski afinitet taloženja na PVDF, koji je također hidrofobne prirode. ${ }^{90}$ Osim PVDF membrana, za primjenu su prikladni i drugi polimerni materijali, npr. politetrafluoretilen (PTFE), ${ }^{91}$ polipropilen (PP), polietersulfon (PES), ${ }^{92}$ polietilentereftalat (PET), ${ }^{93}$ poliuretan (PU), ${ }^{94}$ poliamid (PA) ${ }^{95}$ te poliakrilonitril (PAN). ${ }^{96} \mathrm{Me}-$ đutim, zbog izravnog kontakta membrane s reakcijskom smjesom može doći do abrazije membrane. Zahvaljujući izvrsnim termičkim, kemijskim i mehaničkim značajkama, vrlo dobrom zamjenom za polimerne membrane pokazale su se membrane izrađene od keramičkih materijala, usprkos višim troškovima proizvodnje. Kod priprave membrana od izuzetne je važnosti osigurati stabilnu imobilizaciju katalizatora radi sprječavanja njegova odvajanja od membrane. Za imobilizaciju se primjenjuju razne tehnike. Osim kovalentnim vezivanjem zadovoljavajuća imobilizacija postiže se elektrostatskim vezivanjem putem slabih Van der Waalsovih ili vodikovih veza. ${ }^{97}$ Izvedba PMR-a ovisi o načinu vođenja procesa (šaržni, kontinuirani itd.), o primijenjenoj membranskoj tehnici (ultrafiltracija, nanofiltracija) te o upotrijebljenim membranskim modulima (folije, vlakna itd.). Pritom treba voditi brigu o odgovarajućoj ozračenosti površine fotokatalizatora. ${ }^{98}$

Prednosti FMR-a u odnosu na konvencionalne fotoreaktore su: mogućnost primjene za razgradnju spojeva koji dolaze u različitim agregatnim stanjima, kratko vrijeme reakcije te blagi reakcijski uvjeti (obično atmosferski tlak i sobna temperatura), primjena kisika iz zraka bez potrebe za dodatnim aditivima, razgradnja niskih koncentracija onečišćujućih tvari, razgradnja toksičnih spojeva bez nastajanja neželjenih štetnih produkata, kontrolirano vrijeme zadržavanja molekula onečišćivala te provedba kontinuiranog procesa uz usporedno odvajanje fotokatalizatora od pročišćenog toka otpadne vode. ${ }^{98}$

\subsubsection{Fotokatalitički membranski reaktori sa suspendiranim fotokatalizatorom}

Zahvaljujući velikoj aktivnoj površini fotokatalizatora u suspendiranom obliku, kojom se ostvaruje bolji kontakt foto- katalizatora i onečišćujućih tvari, njihovom primjenom postiže se veća učinkovitost razgradnje u odnosu na reaktore s imobiliziranim fotokatalizatorom. ${ }^{99-103}$ Tri su uobičajene izvedbe FMR-a sa suspendiranim fotokatalizatorom u ulaznoj smjesi s izvorom zračenja koje se može dovoditi: a) na membranski modul, b) u spremnik ulazne smjese ili c) u dodatni fotoreaktor smješten između spremnika reakcijske smjese i membranskog modula. Pritom izvor UV zračenja može biti smješten iznad/unutar/ispod reakcijske smjese, membranskog modula ili dodatnog fotoreaktora. ${ }^{98} \mathrm{~S}$ obzirom na smještaj fotokatalizatora i membrane moguće je razlikovati podijeljeni $\mathrm{i}$ integrirani tip reaktora sa suspendiranim fotokatalizatorom. U prvom slučaju fotokatalitički reaktor i membranski modul potpuno su razdvojeni. Takva strukturirana izvedba povoljna je za njihovu ugradnju i održavanje. Velika prednost izvedbe očituje se u činjenici da ni UV zračenje niti reaktivne vrste kisika neće oštetiti membranu, što je čest slučaj kod reaktora s imobiliziranim fotokatalizatorom zbog izravnog kontakta svjetla i površine membrane. ${ }^{99-102}$

Kod integriranog tipa reaktora fotokatalitička reakcija i membranska separacija provode se unutar istog uređaja. Za izradu membranskog modula uglavnom se upotrebljavaju membrane šupljih vlakana. Membrana je obično uronjena u spremnik sa suspendiranim fotokatalizatorom. Pritom se otopina pod blago negativnim tlakom dovodi s vanjske strane membrane u njezinu unutrašnjost, dok je fotokatalizator raspoređen po vanjskoj površini membrane. U takvoj izvedbi prisutna su samo dva toka, tj. tok ulazne smjese te tok permeata.

Primjer FMR-a s fotokatalizatorom u suspenziji razvili su Chin $i$ sur., ${ }^{103,104}$ a primijenjen je za uklanjanje bisfenola A iz vode. Eksperimentalni sustav sadržavao je reaktor izrađen od borosilikatnog stakla te membranski modul izrađen iz šupljih vlakana koji je smješten po sredini reaktora, dok je UV-A zračenje dovedeno izvana, s četiri strane reaktora.

Potrebno je istaknuti i komercijalni poluindustrijski FMR, koji dolazi pod nazivom Photo-Cat ${ }^{\mathrm{T}}$. Postupak rada tog pilot-uređaja je sljedeći: voda se provodi preko filtra i miješa s gustom suspenzijom $\mathrm{TiO}_{2}$ te se uvodi u reaktor koji se sastoji od niza kanala promjera $3 \mathrm{~mm}$ unutar kojih se nalaze UV-C (254 nm) i vakuum-UV (185 nm) izvori zračenja. Po izlazu iz reaktora smjesa se odvodi na membranski modul koji se sastoji od keramičke membrane, koja omogućava mikrofiltraciju. Fotokatalizator se vraća u proces, a obrađena voda odvodi se iz sustava. Navedeni uređaj pronašao je primjenu za uklanjanje farmaceutika iz rijeke Colorado. ${ }^{105}$ Osim prethodno navedenog, FMR-i čestu primjenu pronalaze pri obradi voda onečišćenih bojilima, herbicidima, površinski aktivnim tvarima (detergentima) i fenolnim spojevima. ${ }^{98}$

\subsubsection{Fotokatalitički membranski reaktori s imobiliziranim katalizatorom}

Drugu skupinu fotokatalitičkih membranskih reaktora čine reaktori čija membrana (polimerna ili keramička) služi kao nosač, a može djelovati i kao svojevrsna barijera molekulama prisutnima u reakcijskoj smjesi. Za razliku od reaktora sa suspendiranim katalizatorom koji mogu biti podi- 
jeljenog ili integriranog tipa, takav tip reaktora isključivo je integrirani, pri čemu se fotokatalitička i membranska reakcija provode unutar iste procesne jedinice. ${ }^{106} \mathrm{U}$ tom slučaju razgradnja prisutne onečišćujuće tvari odigrava se na samoj površini membrane ili unutar njezinih pora. Izvor zračenja obično se smješta iznad membranskog modula neovisno o tome je li katalizator imobiliziran na membrani (slika 4a) ili je smješten unutar membrane (slika 4b). ${ }^{99,107}$

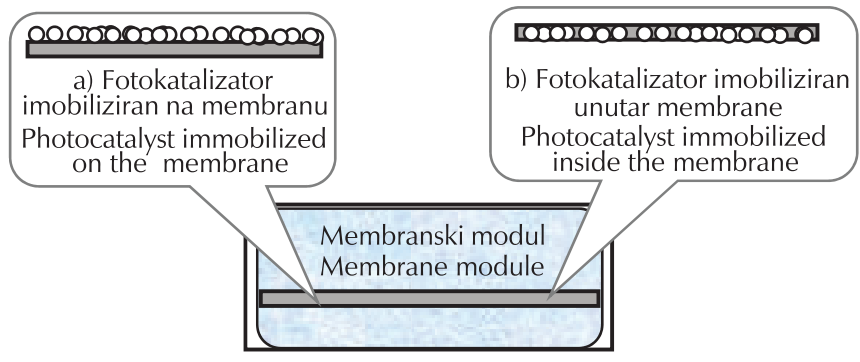

Slika 4 - Izvedba membrane unutar FMR-a: a) fotokatalizator na membrani i b) fotokatalizator unutar membrane

Fig. 4 - Designs of membrane within the PMR: a) photocatalyst on the membrane, and b) photocatalyst inside the membrane

Membrane za fotokatalitičke membranske reaktore mogu se izraditi iz različitih materijala primjenom raznih postupaka izrade. Bosc $i$ sur. ${ }^{87}$ predlažu tzv. asimetrične fotokatalitičke membrane kao optimalne za primjenu u FMRima. Postoje dvije izvedbe asimetričnih fotokatalitičkih membrana s pripadajućim izvorom zračenja. Prvi slučaj, koji je ujedno i češći u primjeni, sastoji se od fotokatalitički aktivnog polupropusnog tankog sloja te od debljeg sloja poroznog nosača. U drugom slučaju tanka polupropusna membrana nije fotokatalitički aktivna, već sam porozni nosač (deblji sloj) predstavlja fotokatalitički aktivnu komponentu. Ovisno o vrsti membrane izvor svjetla može biti smješten na strani reakcijske smjese ili na strani permeata. ${ }^{108,109}$

\subsection{Fotokatalitički monolitni reaktori s optičkim vlaknima}

Razvoj monolitnih katalizatora i/ili reaktora izvorno je inspiriran oponašanjem prirodnih struktura (pčelinje saće). U tehničkoj literaturi pojam monolit odnosi se na tvorevine pravilne i nepromjenjive geometrije, koje sadrže velik broj usporednih kanala, na čije se stijenke nanosi (foto)katalitički aktivan sloj. ${ }^{85,110} \cup$ heterogenoj fotokatalizi pozornost istraživača privukli su keramički monoliti s optičkim vlaknima (engl. optical fibre ceramic monoliths, OFCM) (slika 5). U takvoj izvedbi osnovna monolitna struktura služi kao nosač fotokatalitičkog sloja, dok optička vlakna koja su raspodijeljena uzduž kanalića osnovne monolitne strukture imaju dvostruku ulogu, tj. upotrebljavaju se kao izvor svjetlosti te kao dodatni nosač fotokatalitičkog sloja.

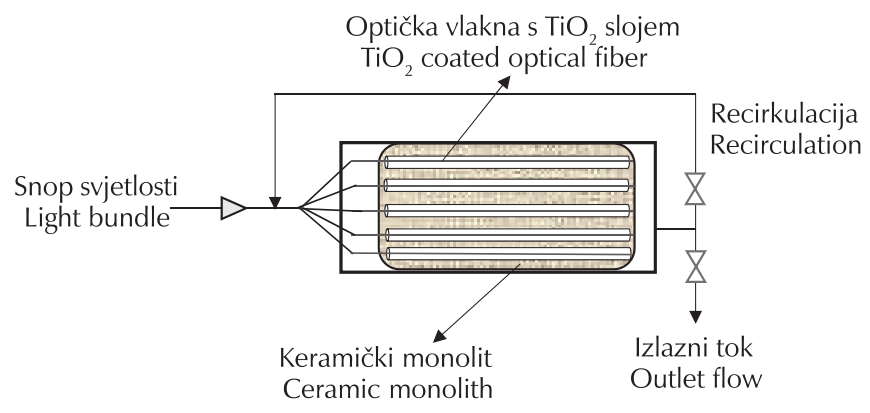

Slika 5 - Fotokatalitički monolitni reaktor s optičkim vlaknima Fig. 5 - Photocatalytic optical fibre monolith reactor

Primjenu optičkih vlakana kao izvora svjetlosti, a istodobno i kao nosača fotokatalitičkog sloja prvi su predložili Mariangeli i Ollis, ${ }^{111}$ dok su Hofstadler i sur. ${ }^{61}$ eksperimentalno ispitali takav sustav primjenom reaktora s kvarcnim vlaknima na čiju površinu je bio imobiliziran sloj $\mathrm{TiO}_{2}$. Međutim, nađeno je da u takvoj jednostavnijoj izvedbi reaktora s optičkim vlaknima (engl. optical fibre reactor, OFR) dolazi do neučinkovitog iskorištenja reakcijskog prostora, jer optička vlakana zauzimaju samo $20-30 \%$ ukupnog volumena reaktora i osiguravaju relativno malu specifičnu površinu dostupnu za nanošenje fotokatalitičkog sloja (jer optička vlakna obično su vrlo tanka). S druge strane, monolitni reaktori s optičkim vlaknima (engl. optical fibre monolith reactor, OFMR) objedinjuju prednosti OFR i monolitnih reaktora te osiguravaju velik omjer specifične površine u odnosu na ukupni volumen reaktora, omogućavaju rad pri velikim protocima reakcijske smjese uz neznatan pad tlaka, a istodobno se postiže jednolika raspodjela UV svjetlosti unutar fizički kompaktnog reaktorskog sustava i velika fotoučinkovitost. Fotoinducirana pobuda fotokatalizatora u takvoj izvedbi reaktora može se opisati na sljedeći način: primjenom sustava leća i reflektora izvor zračenja se u obliku ravnog vala usmjerava na snop vlakana. Kroz optičko vlakno prolazi pozadinsko osvjetljenje, pri čemu val svjetlosti iz vlakana ulazi u sloj $\mathrm{TiO}_{2}$ pod odgovarajućim kutem te dolazi do refrakcije (loma) i/ili refleksije vala. ${ }^{112}$

Refraktirani dio svjetlosti predstavlja izvor pobude za fotokatalitički sloj nanesen na unutarnje stijenke kanalića monolita. Da bi se omogućio prolaz refraktiranog vala u radni medij (fluid) i kasnije do sloja $\mathrm{TiO}_{2}$ na stijenci kanalića monolita, potrebno je minimalizirati utjecaj apsorpcije i raspršenja UV svjetlosti kroz sloj fotokatalizatora na optičkom vlaknu, što se postiže smanjenjem debljine fotokatalitičkog sloja. Utjecaj debljine optičkog vlakna i debljine fotokatalitičkog sloja na vlaknu tijekom fotokatalitičke obrade modelne vode koja je sadržavala 1,2-diklorbenzen (DHB) i fenantren (PHE) opisao je Lin. ${ }^{40}$ Uspoređena su dva slučaja u kojima su upotrijebljena optička vlakna promjera $0,4 \mathrm{~mm}$ i $1 \mathrm{~mm}$. U oba slučaja maksimalne vrijednosti konstante brzine reakcije ostvarene su primjenom fotokatalitički aktivnog sloja debljine $0,4 \mu \mathrm{m}$. Utvrđeno je da s porastom debljine nanesenog aktivnog sloja iznad 0,4 $\mu \mathrm{m}$ dolazi do smanjenja konstante brzine reakcije. Pri debljini od $5 \mu \mathrm{m}$, refraktirana svjetlost gotovo u potpunosti je apsorbirana na sloju $\mathrm{TiO}_{2}$ nanesenom na optička vlakna, čime je izostala fotopobuda fotokatalitičkog sloja na stijenkama kanalića monolita. 


\subsection{Solarni fotoreaktori}

Osim što se primjenjuje pri razgradnji i uklanjanju postojanih organskih spojeva iz otpadnih voda, fotokataliza, a posebice tzv. solarna fotokataliza ili solarna dezinfekcija (engl. solar disinfection, SODIS) ima potencijalnu primjenu za dezinfekciju pitkih voda i uklanjanje mikroorganizama, obradu otpadnih voda iz različitih izvora te za remedijaciju podzemnih voda in situ. Solarna fotokatalitička dezinfekcija pitkih voda razvila se kao logičan slijed razvoja solarne dezinfekcije pitkih voda. Pokazala se "geografski" prihvatljivom metodom koja se spominje još u antičkim vremenima, a posebno je prikladna za pročišćavanje pitkih voda u udaljenim područjima nerazvijenih zemalja koje obiluju Sunčevom svjetlošću. ${ }^{49}$

Vrijeme potrebno za učinkovitu solarnu dezinfekciju znatno se smanjuje dodatkom odgovarajućeg fotokatalizatora koji ubrzava uništavanje mikroorganizama i fotomineralizaciju organskih nečistoća prisutnih u vodi. lako su se mnogi istraživači bavili istraživanjem inaktivacije mikroorganizama pomoću $\mathrm{TiO}_{2}$ fotokatalize, vrlo mali broj istraživanja odnosi se na uvećanje takvih procesa i primjenu Sunčeve energije u realnim uvjetima. Detaljnije informacije o solarnoj fotokatalitičkoj dezinfekciji vode mogu se naći u literaturi. ${ }^{50-57}$

Velik izazov u primjeni solarnih fotoreaktora predstavlja izrada solarnih fotoreaktora koji se znatno razlikuju od uobičajenih kemijskih reaktora. Naime, da bi se moglo iskoristiti Sunčevo zračenje koje će omogućiti uklanjanje onečišćenja, reaktor mora biti izrađen od transparentnog materijala što istodobno uzrokuje probleme vezane uz brtvljenje, rizik od loma, a ograničava i veličinu reaktora. Prema tome, pri izvedbi takvih reaktora od presudne je važnosti geometrija, dok su uobičajeni procesni parametri poput temperature, tlaka i miješanja manje važni. Vrlo je malo materijala koji su transparentni za Sunčevo zračenje, a istodobno mehanički stabilni. Fluorirani i akrilni polimeri te pojedine vrste stakla su materijali koji ispunjavaju navedene zahtjeve. Fluorirane polimere od ostalih materijala izdvaja visoka propusnost za UV zračenje te dobra kemijska stabilnost. Dobru toplinsku i kemijsku otpornost kao i zadovoljavajuću propusnost Sunčeva zračenja pokazuje kvarc. Međutim, ograničavajući čimbenik je njegova visoka cijena, koja izradu reaktora većih dimenzija čini ekonomski neprihvatljivom. Dodatni problem koji ograničava učinkovitost fotokatalitičke obrade je nakupljanje mikroorganizama na stijenkama reaktora. Kao potencijalno rješenje tog problema upotrebljavaju se koncentrirajuće i reflektirajuće površine koje se izrađuju od ekonomski prihvatljivog aluminija, dok se za izradu reaktorskih cijevi često upotrebljavaju polietilen i polipropilen. ${ }^{113} \mathrm{~S}$ obzirom na izvedbu zračenja, moguće je razlikovati solarne reaktore s koncentriranim i nekoncentriranim zračenjem. $U$ primjeni se češće nalaze reaktori s nekoncentriranim zračenjem, koji osim izravnog mogu rabiti i difuzno Sunčevo zračenje, što im, osim tijekom sunčanih, omogućuje i rad tijekom oblačnih dana. Posljednjih 15 godina razvijeni su i testirani brojni solarni fotoreaktori. U nastavku su detaljnije opisana tri najčešće upotrebljavana tipa solarnih fotoreaktora.

\subsubsection{Solarni reaktor s paraboličnim zrcalom}

Solarni reaktor s paraboličnim zrcalom (engl. parabolic trough reactor, PTR) primjer je reaktora s koncentriranim zračenjem. Učinkovito iskorištava izravno Sunčevo zračenje, a njegova dodatna prednost jeste u tome što omogućava primjenu prikupljene toplinske energije za druge svrhe. Solarni reaktor s paraboličnim zrcalom sastoji se od transparentne reaktorske cijevi kroz koju protječe onečišćena voda, slika 6. Cijev se nalazi u centralnom dijelu kolektora - paraboličnog zrcala odnosno zrcalne površine u obliku rotacijskoga paraboloida (obično je presvučena srebrom ili poliranim aluminijem) koja reflektira Sunčevu svjetlost i koncentrira ju u žarište odnosno usmjerava zračenje na radni medij u cijevi. Kolektor je postavljen na linijskoj pokretnoj platformi opremljenoj sustavom za praćenje položaja Sunca. Kako se tijekom dana položaj Sunca mijenja, tako se mijenja i najpovoljniji kut pod kojim Sunčeve zrake padaju na površinu reflektora. PTR omogućava rad pri velikim protocima onečišćene vode, pri čemu turbulentan tok osigurava zadovoljavajuću brzinu međufaznog prijenosa tvari između radnog fluida i površine fotokatalizatora. ${ }^{114}$

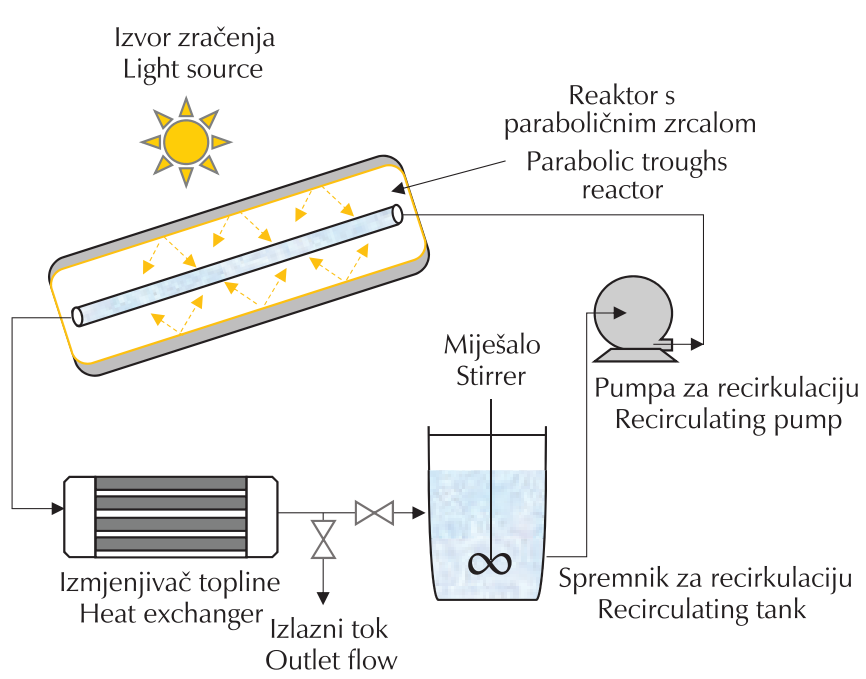

Slika 6 - Reaktor s paraboličnim zrcalom ${ }^{114}$

Fig. 6 - Parabolic trough reactor ${ }^{114}$

Takva izvedba reaktora primjenjuje se u Nacionalnom laboratoriju Sandia u Novom Meksiku za obradu vode onečišćene salicilnom kiselinom. Karakteristične ukupne dimenzije reaktorskog sustava iznose $218 \mathrm{~m} \times 2,1 \mathrm{~m}$ (duljina $\times$ širina), a sustav sadrži borosilikatnu staklenu cijev promjera $38 \mathrm{~mm}$. Reaktor je šaržnog tipa uz recirkulaciju reakcijske smjese u kojoj je suspendiran $\mathrm{TiO}_{2}$. Za hlađenje se primjenjuje zračni izmjenjivač topline. $U$ navedenom reaktoru provedena je obrada 100 I vode onečišćene salicilnom kiselinom, pri čemu je $26 \%$-tna razgradnja postignuta tijekom 40 min. Slična pilot-postrojenja razvijena su u Španjolskoj (CIEMAT), SAD-u (National Renewable Energy Laboratory, NREL) i drugdje, a razlog tome je činjenica da se izvedbe PTR-a uspješno primjenjuju za razgradnju različitih onečišćenja, uključujući pesticide, metalne komplekse, bakterije i druga onečišćenja. Treba napomenuti da 
su u takvim pilot-postrojenjima uobičajene izvedbe PTR-a koje sadrže velik broj usporedno povezanih reaktorskih cijevi, pri čemu je svaka cijev opremljena odgovarajućim paraboličnim zrcalom/reflektorom. Također postoje izvedbe PTR-a s imobiliziranim slojem fotokatalizatora, kao i izvedbe koje ne sadrže fotokatalizator (npr. PROPHIS u Njemačkoj).

Potencijalni nedostatci PTR-a su: velika površina za instaliranje sustava (zbog velike površine paraboličkih zrcala), mala učinkovitost tijekom oblačnih dana, pregrijavanje radnog medija i dr. Pregrijavanje radnog medija nije poželjno jer može dovesti do gubitka radnog medija (zbog propuštanja cijevi), korozije, kao i zbog neprihvatljive toplinske učinkovitosti. S porastom temperature smanjuje se topljivost kisika u vodi, što može dovesti do nastajanja mjehurića. Da bi se izbjeglo nastajanje mjehurića, ponekad se dodaju tzv. zamke elektrona, kao što su vodikov peroksid/ natrijev persulfat i sl., međutim primjena dodatnih kemikalija otežava primjenu takvih procesa u realnim sustavima. ${ }^{114}$

\subsubsection{Solarni reaktor s nepokretnim tankim slojem fotokatalizatora}

Reaktor s tankim slojem fotokatalizatora (engl. thin film fixed bed reactor, TFFBR) jedan je od prvih fotoreaktora koji, iako ne primjenjuje sustav koncentriranja svjetlosti, može rabiti i difuzni i izravni dio UV-A spektra. Osnovni dio takvog sustava čini staklena ploča karakterističnih dimenzija (npr. 0,6 m × 1,2 m) s impregniranim slojem fotokatalizatora koja je nagnuta pod određenim kutem, preko koje u tankom sloju cirkulira radni medij. Pomoću pumpe regulira se protok onečišćene vode koji može dolaziti u širokom rasponu (npr. $1-6,5 \mathrm{Ih}^{-1}$ ). Osnovna izvedba takvog reaktora prikazana je na slici $7 .{ }^{115}$ Glavne prednosti reaktora su: primjena cijelog spektra UV zračenja, visoka

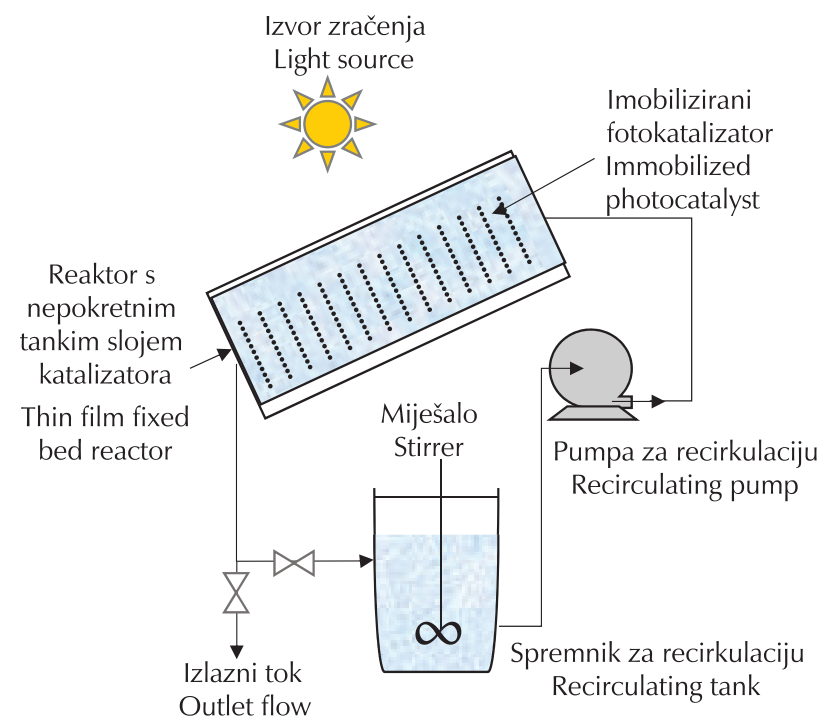

Slika 7 - Reaktor s nepokretnim tankim slojem ${ }^{115}$ Fig. 7 - Thin film fixed bed reactor ${ }^{115}$ optička učinkovitost, jednostavnost izvedbe te izostajanje potrebe za naknadom separacijom fotokatalizatora (jer se primjenjuje imobiliziran sloj fotokatalizatora). S druge strane, laminarno strujanje, isparavanje prisutnih nečistoća, površina fotokatalizatora izložena eventualnim nečistoćama te velika površina potrebna za obradu velikih volumena otpadnih voda neki su od nedostataka tih sustava. ${ }^{24}$

\subsubsection{Reaktor s paraboličnim zrcalom $i$ nekoncentriranim zračenjem}

Problemi vezani uz primjenu PTR-a mogu se izbjeći primjenom reaktora s paraboličnim zrcalom i nekoncentriranim zračenjem (engl. compound parabolic collector, CPC). CPC su statični (nepokretni) reaktori koji se sastoje od transparentnih cijevi pričvršćenih na reflektor, pri čemu je osnovna izvedba reaktora slična PTR-u, a uglavnom se razlikuju s obzirom na izvedbu kolektora, odnosno reflektirajućeg zrcala. Reflektor najčešće ima karakterističan oblik koji se može predočiti pomoću dviju polovina parabola koje se sijeku ispod svake reaktorske cijevi. Takav oblik reflektora omogućava usmjeravanje upadne zrake Sunčeve svjetlosti na prozirnu reaktorsku cijev bez potrebe za dodatnim sustavom za praćenje položaja Sunca. Prednost CPC izvedbe nalazi se u homogenoj refleksiji izravnog i difuznog zračenja na površinu reaktorskih cijevi, pri čemu se maksimalno iskorištava Sunčevo zračenje. Na taj način povećava se ukupan broj fotona dostupnih za fotoinduciranu aktivaciju katalizatora u CPC fotoreaktoru, a istodobno se omogućava rad tijekom oblačnih dana kad je nedostupno izravno Sunčevo zračenje, odnosno kad je dostupno samo difuzno zračenje. Zbog bolje raspodjele zračenja po čitavoj površini reaktorske cijevi poboljšana je i raspodjela zračenja na fotokatalizatoru u usporedbi s PTR-om gdje je zračenje koncentrirano na donju polovicu reaktorske cijevi. Zbog homogenije raspodjele zračenja CPC prikladni su i za primjenu sloja fotokatalizatora imobiliziranog na odgovarajući nosač smješten unutar reaktorske cijevi (npr. vulkanski porozni kamen, staklene kuglice i sl.), čime se izbjegava skupa naknadna separacija fotokatalizatora. Međutim, u tom slučaju može doći do začepljenja reaktora, prljanja fotokatalizatora i veći su troškovi vezani uz rad pumpe, što otežava prenošenje na veće mjerilo i komercijalizaciju. Nadalje, kod CPC-a nema potrebe za dodatnim mehanizmom za praćenje položaja Sunca, što znatno smanjuje složenost i ukupne troškove sustava. Uz odgovarajuću izvedbu CPC može omogućiti i koncentriranje Sunčeva zračenja na sličan način kao i kod PTR-a, ali u tom slučaju ne može se iskoristiti difuzno Sunčevo zračenje.

Nedostatci CPC-a s nekoncentriranim zračenjem su sljedeći: a) potrebna je veća količina fotokatalizatora u usporedbi s PTR-om i b) reaktorske cijevi su većeg promjera, što podrazumijeva i niže radne tlakove. Za razliku od PTR-a, površina reaktorske cijevi u CPC izvedbi s nekoncentriranim zračenjem mora biti izjednačena s površinom reflektora koji se nalazi iza nje, što u konačnici ograničava veličinu reflektora. Međutim, ti problemi nisu jako izraženi i mogu se uspješno rješavati primjenom metoda sistemskog inženjerstva. ${ }^{116} \mathrm{CPC}$ izvedba obično podrazumijeva kontinuirano dovođenje kisika reakcijskoj smjesi ili primjenu oksidansa, kao što su vodikov peroksid i natrijev persulfat. 
Primjer demonstracijskog postrojenja koje se zasniva na primjeni CPC reaktora je HIDROCEN u Madridu. To postrojenje u potpunosti je automatizirano, uključuje šaržni način rada uz recirkulaciju reakcijske smjese te površinu ulaznog Sunčeva zračenja od $100 \mathrm{~m}^{2}$, a omogućava obradu 1000 I vode. Nakon provedenog postupka podešava se $\mathrm{pH}$ u sedimentacijskoj posudi da bi se poboljšala aglomeracija $\mathrm{TiO}_{2}$ u veće čestice i olakšala njegova separacija taloženjem i mikrofiltracijom u završnom stupnju procesa. Slična demonstracijska i pilot-postrojenja nalaze se u Almeriji (Plataforma Solar de Almeria, PSA) i upotrebljavaju se za uklanjanje cijanida. ${ }^{14}$ Jedan od PSA sustava - CPC-SODIS sastoji se od dvije borosilikatne staklene cijevi od $50 \mathrm{~mm}$ vanjskog promjera postavljene na fiksnu platformu nagiba $37^{\circ}$. Takva jednostavna izvedba pilota omogućava obradu 14 I vode. Složeniji sustav FITOSOL uključuje CPC reaktor s mogućnošću obrade 60 - 100 I vode. Sustav je opremljen pH uređajima i senzorima otopljenog kisika koji su povezani s kontrolnim uređajem za automatsko prikupljanje podataka. Za taj fotoreaktor projektiran je i ugrađen sustav za grijanje i hlađenje radi održavanja temperature vode između 15 i $45{ }^{\circ} \mathrm{C}$. Različite točke ubrizgavanja zraka dodane su kako bi se povećao dotok otopljenog kisika u sustav. ${ }^{117}$

Na slici 8 prikazan je CPC u šaržnom načinu rada uz recirkulaciju reakcijske smjese i primjenu suspendiranog fotokatalizatora.

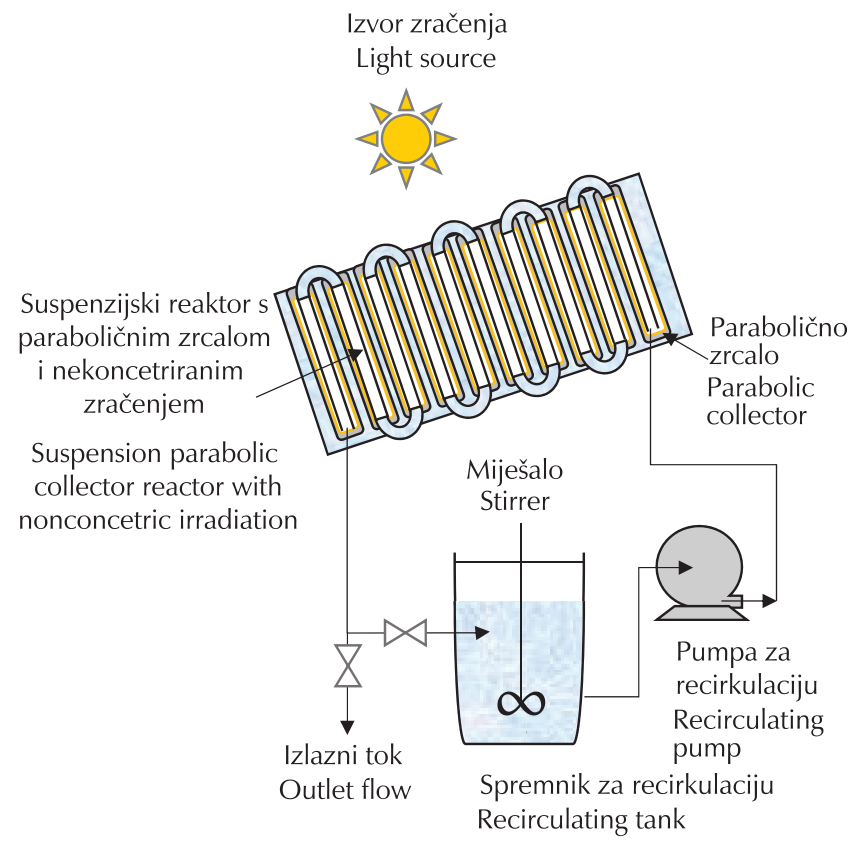

Slika 8 - Shematski prikaz suspenzijskog CPC sustava ${ }^{114}$ Fig. 8 - Schematic drawing of slurry CPC system ${ }^{114}$

\section{Zaključak}

Onečišćenje okoliša problem je kojem se u današnje vrijeme posvećuje sve veća pažnja. Jedan od glavnih problema svakako je nedostatan pristup čistoj vodi. Pored tradici- onalnih postupaka obrade onečišćenih voda, zraka i tla, fotokatalitički procesi poprimaju sve važniju ulogu u zaštiti okoliša.

Napredne izvedbe tzv. strukturiranih reaktora (mikroreaktori, membranski reaktori, monolitni reaktori) koje su nastale kao rezultat primjene metodologije intenzifikacije procesa, osiguravaju visoku preciznost u katalitičkim procesima, a njihovom primjenom ostvaruju se očekivani rezultati. Glavna prednost mikroreaktora očituje se u velikom omjeru površine i volumena te jednostavnom uvećanju procesa. Relativno nova, ali obećavajuća tehnologija koja bi se potencijalno mogla primijeniti u raznim područjima ljudske djelatnosti, od obrade voda i otpadnih voda do organske sinteze, zasniva se na integriranju heterogene fotokatalize i membranskih procesa. Fotokatalitički membranski reaktori uključuju različite izvedbe reaktora s obzirom na način primjene fotokatalizatora, odnos membranskog modula i UV zračenja te s obzirom na izvedbu i značajke primijenjene membrane. Takvi reaktori imaju brojne prednosti u odnosu na konvencionalne izvedbe fotoreaktora, a mogućnost njihovih dodatnih izmjena ostavlja prostor za niz budućih istraživanja. lako fotokatalitički membranski reaktori imaju velik potencijal za obradu voda, još uvijek postoje ozbiljni izazovi u pogledu stabilnosti membrana, investicijskih troškova i troškova rada. Velike potencijale za provedbu fotokatalitičkih procesa obrade voda pokazuju i monoliti. Stoga se često upotrebljavaju u znanstvenim istraživanjima $i$ istražuju mogućnosti njihove primjene $u$ realnim sustavima. Monolitna izvedba reaktora integrirana s optičkim vlaknima kao izvorima fotoinducirane pobude fotokatalizatora i ujedno potencijalnim nosačima fotoaktivnog sloja omogućuje provođenje fotokatalitičkih procesa pri velikim radnim protocima, uz zanemariv otpor prijenosu tvari i visoku fotoučinkovitost. Od 1990. intenzivno se počinju razvijati solarna fotokatalitička demonstracijska i pilot-postrojenja za obradu voda i uklanjanje različitih toksičnih spojeva prisutnih u vodama, (kao što su salicilna kiselina, trikloro-etilen, pentaklorofenol, BTEX, cijanidi, aromatski pojevi, fenoli, amonijak i dr.). Do sada su intenzivno izučavane različite izvedbe solarnih fotoreaktora, kao što su reaktor s paraboličnim zrcalom (PTR), reaktor s tankim slojem fotokatalizatora (TFFBR), reaktor s paraboličnim zrcalom i nekoncentriranim zračenjem (CPC), kao i izvedbe koje nisu opisane u ovom radu, a privukle su pažnju brojnih istraživača, kao što su reaktor s padajućim filmom (engl. falling film reactor), kaskadni reaktor s padajućim filmom (engl. thin film cascade reactor), plitki reaktor (engl. shallow pond reactor) i dr. lako su prethodno spomenute izvedbe solarnih fotokatalitičkih reaktora pokazale veliku učinkovitost tijekom obrade podzemnih, industrijskih, komunalnih i pitkih voda, primjeri njihove komercijalne primjene još uvijek su relativno malobrojni, što nameće potrebu za budućim istraživanjima. $U$ ovom radu dan je pregled naprednih izvedbi fotoreaktora koje su nastale primjenom metodologije intenzifikacije procesa, pri čemu su zbog opsežnosti problematike izdvojeni samo odabrani primjeri takvog pristupa. Takve izvedbe fotoreaktora primjenjivane su za uklanjanje različitih onečišćenja uporabom prirodnog ili simuliranog Sunčeva zračenja. I na kraju, logično se nameće pitanje: koja je od prethodno opisanih izvedbi najprikladnija za provedbu fotokatalitičkih procesa s obzirom na uvećanje procesa i potencijalnu komerci- 
jalizaciju? Da bi se odgovorilo na to pitanje, potrebno je pronaći odgovarajući kriterij koji će omogućiti usporedbu različitih izvedbi i izbor optimalnog fotoreaktora s obzirom na prisutno onečišćenje i cilj koji se želi postići. Međutim, to će biti tema nekog budućeg preglednog rada.

\section{ZAHVALA}

Rad je nastao u okviru projekata "Intenzifikacija fotokatalitičkih i katalitičkih procesa za obradu otpadnih voda i otpadnih plinova", IN-PhotoCat (IP-2018-01-8669), koji financira Hrvatska zaklada za znanost te "Otpad i sunce za fotokatalitičku razgradnju mikrozagađivača u vodi" (OS-Mi) Europskog fonda za regionalni razvoj EU, KK.01.1.1.04.0006.

\section{Popis kratica \\ List of abbreviations}

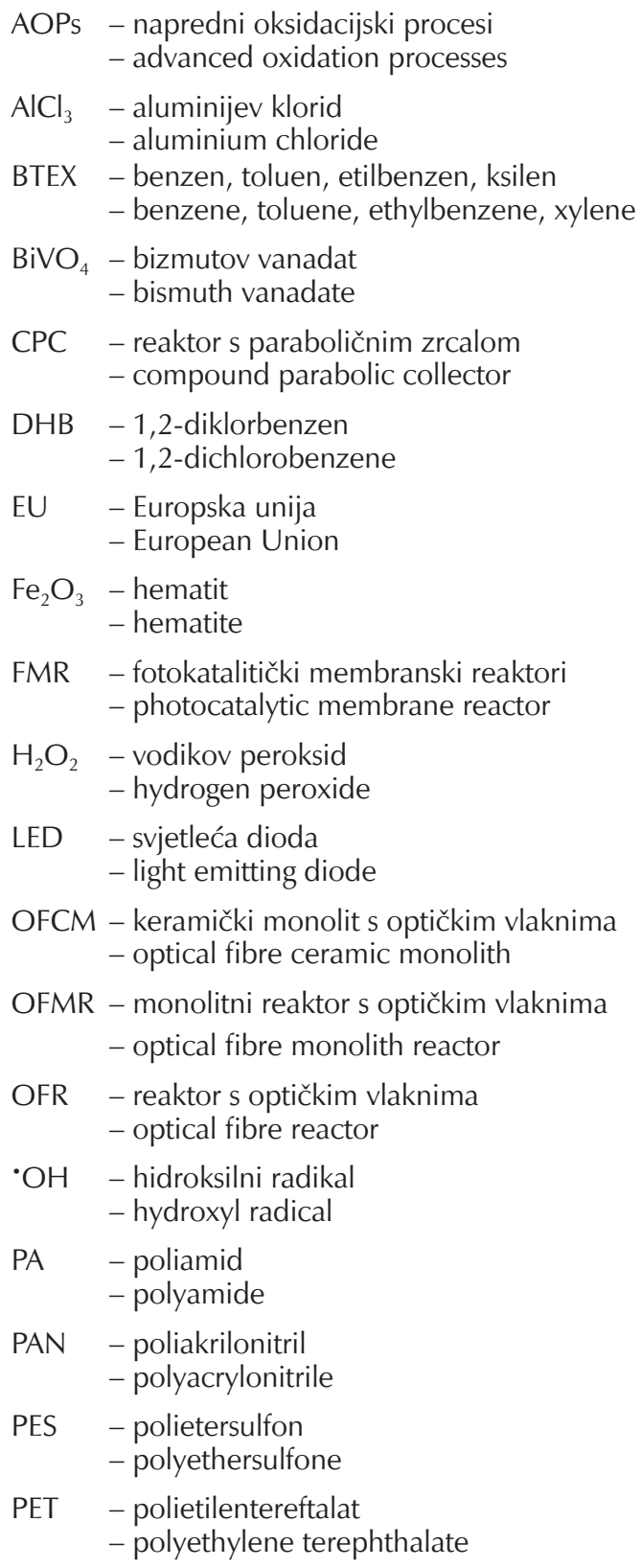

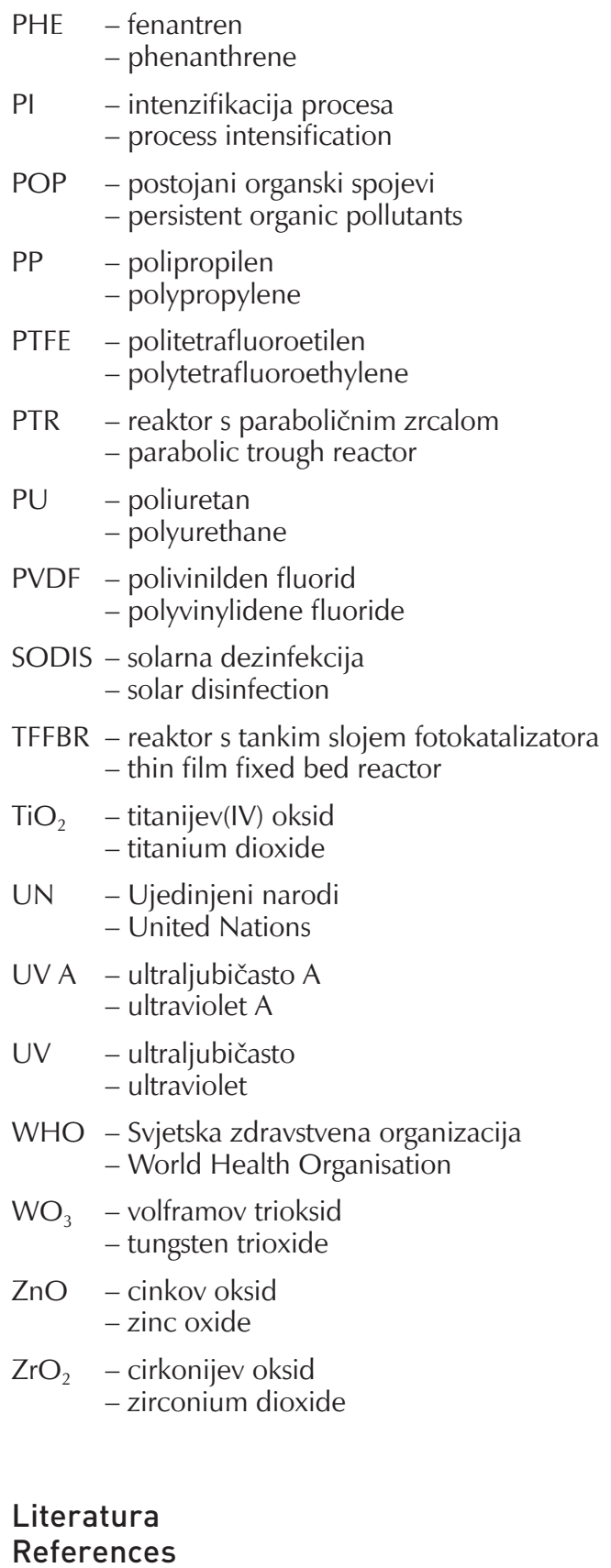

1. G. Kleemann, K. Hartmann, Z. Wiss, Tech. Hochschule "Carl Schorlemmer", Leuna Merseburg 20 (1978) 417.

2. C. Ramshaw, Higee distillation-an example of process intensification, Chem. Eng. 389 (1983) 13-14.

3. A. I Stankiewicz, J. A. Moulijn, Process intensification: transforming chemical engineering, Chem. Eng. Prog. 96 (2000) 22-34, doi: http://doi.org/10.4236/oalib.1104694.

4. J.-C. Charpentier, Process intensification by miniaturization, Chem. Eng. Technol. 28 (2005) 255-258, doi: https://doi. org/10.1002/ceat.200407026.

5. A. Hüther, A. Geißelmann, H. Hahn, Process intensification: A strategic option for the chemical industry, Chem. Ing. Tech. 77 (2005) 1829-1837, doi: https://doi.org/10.1002/ cite. 200500144

6. J. A. Moulijn, A. Stankiewitz, J. Grievink, A. Górak, Process intensification and process system engineering: A friendly symbiosis, Comp. Chem. Eng. 32 (2008) 3-11, doi: https:// doi.org/10.1016/j.compchemeng.2007.05.014. 
7. URL: http://www.pi-inc.co/services.html (pristup 1. ožujka 2020.).

8. F. Jović, V. Tomašić, Heterogena fotokataliza: osnove i primjena za obradu onečišćenog zraka, Kem. Ind. 60 (2011) 387-403, doi: https://doi.org/10.15255/KUI.2010.027.

9. URL: http://www.un.org/waterforlifedecade/human_right to water.shtml (pristup 1. ožujka 2020.).

10. URL: http://www.un.org/waterforlifedecade/pdf/facts_and figures_human_right_to_water_eng.pdf (pristup 12. siječnja 2015.).

11. Resolution $A / R E S / 64 / 292$. The human right to water and sanitation. United Nations General Assembly, 2010.

12. Regulation (EC) No 850/2004 of the European Parliament and of the Council of 29 April 2004 on persistent organic pollutants and amending Directive 79/117/EEC.

13. D. Dionysiou, Potential and limits of biodegradation processes for the removal of organic xenobiotics from wastewaters, Chem. Bio. Eng. Rev. 2 (2014) 67-82, doi: https://doi. org/10.1002/cben.201300008.

14. URL: https://www.intechopen.com/books/water-treatment (pristup 4. ožujka 2020.).

15. S. Kommineni, J. Zoeckler, A. Stocking, S. Liang, A. Flore, M. Kavanaugh, R. Rodriguez, T. Browne, R. Roberts, A. Brown, Advanced Oxidation Processes, Fountain Valley (CA): National Water Research Institute, 2008., str. 111-207.

16. R. Munter, Advanced Oxidation Processes - Current Status and Prospects, Proc. Estonian Acad. Sci. Chem. 50 (2001) 59-80, doi: https://doi.org/10.4236/snl.2020.102002.

17. J. Hoigne, Inter-calibration of radical sources and water quality parameters, Water Sci. Technol. 35 (4) (1997) 1-8, doi: https://doi.org/10.1016/S0273-1223(97)00002-4.

18. R. Andreozzi, V. Caprio, A. Insola, R. Marotta, Advanced oxidation processes (AOP) for water purification and recovery, Catal. Today 53 (1999) 51-59, doi: https://doi.org/10.1016/ S0920-5861(99)00102-9.

19. S. H. S. Chan, T. Y. Wu, J. C. Juan, C. Y. Teh, Recent developments of metal oxide semiconductors as photocatalysts in advanced oxidation processes (AOPs) for treatment of dye waste-water, J. Chem. Technol. Biot. 86 (2011) 1130-1158, doi: https://doi.org/10.1002/jctb.2636.

20. A. Di Paola, E. Garcia-Lopez, G. Marci, L. Palmisano, A survey of photocatalytic materials for environmental remediation, J. Hazard. Mater. 211 (2012) 211-212, doi: https://doi. org/10.1016/j.jhazmat.2011.11.050.

21. X. Zhu, C. Yuan, Y. Bao, J. Yang, Y. Wu, Photocatalytic degradation of pesticide pyridaben on $\mathrm{TiO}_{2}$ particles, J. Mol. Catal: Chemical 229 (2005) 95-105, doi: https://doi.org/10.1021/ es061178+.

22. M. Abdullah, G. Law, R. W. Mathews, Effects of common inorganic anions on rates of photocatalytic oxidation of organic carbon over illuminated titanium dioxide, J. Phys. Chem. 94 (1990) 6820-6825, doi: https://doi.org/10.1021/ j100380a051.

23. Y. Parent, D. Blake, B. K. Magrini, C. Lyons, A. Turchi, E. Watt, M. Praire, Solar photocatalytic processes for the purification of water: State of development and barriers to commercialization, Solar Energy 56 (1996) 429-437, doi: https://doi. org/10.1016/0038-092X(96)81767-1.

24. H. De Lasa, B. Serrano, M. Salaices, Advances and Perspectives for Photocatalysis, u Photocatalytic Reaction Engineering, Springer, New York, 2005., str. 169-183, doi: https:// doi.org/10.1007/0-387-27591-6_9.

25. P. Wyness, J. F. Klausner, D. Y. Goswami, Performance of nonconcentrating solar photocatalytic oxidation reactors, Part II: shallow pond configuration, J. Solar Energy Eng. 116 (1994) 8-13, doi: https://doi.org/10.1115/1.2930069.

26. S. Mozia, Photocatalytic membrane reactors (PMRs) in water and wastewater treatment, Sep. Purif. Technol. 73 (2) (2010) 71-91, doi: https://doi.org/10.1016/J.SEPPUR.2010.03.021.

27. S. S. Chin, K. Chiang, A. G. Fane, The stability of polymeric membranes in $\mathrm{TiO}_{2}$ photocatalysis process, J. Memb. Sci. 275 (1-2) (2006) 202-211, doi: https://doi.org/10.1016/j. memsci.2005.09.033.

28. J. Fernandez, J. Kiwi, C. Lizama, J. Freer, J. Baeza, H. D. Mansilla, Factorial experimental design of Orange II photocatalytic discolouration, J. Photochem. Photobiol. A: Chem. 151 (2002) 213-219, doi. https://doi.org/10.1016/S10106030(02)00153-3.

29. T. Torimoto, S. Ito, S. Kuwabata, Effects of adsorbents used as supports for titanium dioxide loading on photocatalytic degradation of propyzamide, Environ. Sci. Tech. 30 (4) (1994) 1275-1281, doi: https://doi.org/10.1021/es950483k.

30. K. Hofstadler, R. Bauner, S. Novallc, K. Heisler, New reactor design for photocatalytic wastewater treatment with $\mathrm{TiO}_{2}$ immobilized on fused-silica glass fibers: photomineralization of 4-chlorophenol, Environ. Sci. Tech. 28 (1994) 670-674, doi: https://doi.org/10.1021/es00053a021.

31. N. J. Peil, M. R. Hoffman, J. Photocatalytic fiber-optic cable reactor for waste stream remediation, Solar Energy Eng. 119 (1997) 229-235, doi: https://doi.org/10.1115/1.2888024.

32. Y. Zhang, J. C. Crittenden, D. W. Hand, Fixed-bed photocatalysts for solar decontamination of water, Environ. Sci. Tech. 28 (1994) 435-442, doi: https://doi.org/10.1021/ es00052a015.

33. N. Serpone, E. Borgarello, R. Harris, P. Cahill, M. Borgarello, E. Pelizzetti, Photocatalysis over $\mathrm{TiO}_{2}$ supported on a glass substrate, Sol. Energy Mater. 14 (1986) 121-127, doi: https:// doi.org/10.1016/0165-1633(86)90070-5.

34. I. R. Bellobono, A. Carrara, B. Barni, A. Gazzotti, Laboratory and pilot-plant scale photodegradation of chloroaliphatics in aqueous solution by photocatalytic membranes immobilizing titanium dioxide, J. Photochem. Photobiol. A: Chem. 84 (1994) 83-90, doi: https://doi.org/10.1016/10106030(94)03844-9.

35. R. L. Pozzo, J. L. Giombi, M. A. Baltanas, A. E. Cassano, The performance in a fluidized bed reactor of photocatalysts immobilized onto inert supports, Catal. Today 62 (2000) 175187, doi: https://doi.org/10.1016/S0920-5861(00)00419-3.

36. G. Low, R. W. Matthews, Flow-injection determination of organic contaminants in water using an ultraviolet mediated titanium dioxide film reactor, Anal. Chim. Acta 231 (1990) 13-20, doi: https://doi.org/10.1016/S0003-2670(00)863916.

37. N. J. Peil, M. R. Hoffman, Chemical and physical characterization of a $\mathrm{TiO}_{2}$ - coated fiber optic cable reactor, Environ. Sci. Tech. 32 (3) (1998) 398, doi: https://doi.org/10.1021/ es960047d.

38. A. K. Ray, A. Beenackers, Development of a new photocatalytic reactor for water purification, Catal. Today 40 (1998) 73, doi: https://doi.org/10.1016/S0920-5861(97)00123-5.

39. A. D. Keane, K. G. McGuigan, P. Fernández Ibáñez, M. I. Polo-López, J. A. Byrne, S. M. Dunlop, K. O'Shea, D. D. Dionysioug, S. C. Pillai, Solar photocatalysis for water disinfection: Materials and reactor design, Catal. Sci. Technol. 4 (2014) 1211-1226, doi: https://doi.org/10.1039/C4CY00006D.

40. H. Lin, Photocatalysis in a novel semiconducting optical fiber monolithic reactor for wastewater treatment, PhD Thesis, Louisiana State University, 2005.

41. L. Ridel, A. Wehrer, D. Ronze, A. Zolalian, Photocatalysis 
in a novel semiconducting optical fiber monolithic reactor for wastewater treatment, Ind. Eng. Chem. Res. 36 (1997) 4712, doi: https://doi.org/10.1021/ie970100m.

42. R. L. Romero, O. M. Alfano, A. E. Cassano, Radiation field in an annular, slurry photocatalytic reactor, Ind. Eng. Chem. Res. 42 (2003) 2479-2488, doi: https://doi.org/10.1021/ ie020588d.

43. G. L. Puma, P. L. Yue, A laminar falling film slurry photocatalytic reactor. Part I - Model development, Chem. Eng. Sci. 53 (1998) 2993-3006, doi: https://doi.org/10.1016/S00092509(98)00120-1.

44. J. G. Sczechowski, C. A. Koval, R. D. Noble, A Taylor vortex reactor for heterogeneous photocatalysis, Chem. Eng. Sci. 50 (1995) 3163-3173, doi: https://doi.org/10.1016/00092509(95)00176-6.

45. P. Gao, W. H. Ching, M. Herrmann, C. K. Chan, P. L. Yue, Photooxidation of a model pollutant in an oscillatory flow reactor with baffles, Chem. Eng. Sci. 58 (2003) 1013-1020, doi: https://doi.org/10.1016/S0009-2509(02)00642-5.

46. A. Sobczynski, J. Gimenez, S. CerveraMarch, Photodecomposition of phenol in a flow reactor: Adsorption and kinetics, Monatsh. Chem. 128 (1997) 1109-1118, doi: https://doi. org/10.1007/BF00807561.

47. L. G. Puma, P. L. Yue, The modeling of a fountain photocatalytic reactor with a parabolic profile, Chem. Eng. Sci. 56 (2001) 721-726, doi: https://doi.org/10.1016/S00092509(00)00281-5.

48. D. W. Chen, A. K. Ray, Photodegradation kinetics of 4-nitrophenol in $\mathrm{TiO}_{2}$ suspensions, Water Res. 32 (1998) 32233234, doi: https://doi.org/10.1016/S0043-1354(98)001183.

49. S. P. Kamble, S. P. Deosarkar, S. B. Sawant, J. A. Moulijn, V. G. Pangarkar, Photocatalytic degradation of 2,4-dichlorophenoxyacetic acid using concentrated solar radiation: Batch and continuous operation, Ind. Eng. Chem. Res. 43 (2004) 8178-8187, doi: https://doi.org/10.1021/ie0494263.

50. A. K. Ray, A. A. C. M. Beenackers, Novel photocatalytic reactor for water purification, AIChE J. 44 (1998) 477-483, doi: https://doi.org/10.1002/aic.690440224.

51. I. Mazzarino, P. Piccinini, L. Spinelli, Degradation of organic pollutants in water by photochemical reactors, Catal. Today 48 (1999) 315-321, doi: https://doi.org/10.1016/S09205861(98)00387-3.

52. G. B. Raupp, J. A. Nico, S. Annangi, R. Changrani, R. Annapragada, Two-flux radiation-field model for an annular packedbed photocatalytic oxidation reactor, AIChE J. 43 (1997) 792-801, doi: https://doi.org/10.1002/aic.690430324.

53. T. K. Sengupta, M. F. Kabir, A. K. Ray, A Taylor vortex photocatalytic reactor for water purification, Ind. Eng. Chem. Res. 40 (2001) 5268-5281, doi: https://doi.org/10.1021/ ie001120i.

54. R. Molinari, F. Pirillo, M. Falco, V. Loddo, L. Palmisano, Photocatalytic degradation of dye by using a membrane reactor, Chem. Eng. Proc. 43 (2004) 1103-1114, doi: https://doi. org/10.1016/j.cep.2004.01.008.

55. A. Bhargava, M. F. Kabir, E. Vaisman, C. H. Langford, A. Kantzas, Novel technique to characterize the hydrodynamics and analyze the performance of a fluidized-bed photocatalytic reactor for wastewater treatment, Ind. Eng. Chem. Res. 43 (2004) 980-989, doi: https://doi.org/10.1021/ie030473p.

56. B. Serrano, H. De Lasa, Photocatalytic degradation of water organic pollutants: Kinetic and energy modeling, Ind. Eng. Chem. Res. 36 (1997) 4705-4711, doi: https://doi. org/10.1021/ie970104r.

57. D. D. Dionysiou, G. Balasubramanian, M. T. Suidan, A. P.
Khodadoust, I. Baudin, M. Laine, Rotating disk photocatalytic reactor: development, characterization, and evaluation for the destruction of organic pollutants, Water Res. 34 (2000) 2927-2940, doi: https://doi.org/10.1016/S00431354(00)00022-1.

58. H. Lin, K. T. J. Valsaraj, A titania thin film annular photocatalytic reactor for the degradation of polycyclic aromatic hydrocarbons in dilute water streams, J. Hazard. Mater. 99 (2003) 203-219, doi: https://doi.org/10.1016/S03043894(03)00060-8.

59. S. Zhou, A. K. Ray, Kinetic studies for photocatalytic degradation of eosin B on a thin film of titanium dioxide, Ind. Eng. Chem. Res. 42 (2003) 6020-6033, doi: https://doi. org/10.1021/ie030366v.

60. H. Al-Ekabi, N. J. Serpone, Photocatalytic Purification of Water and Air, Phys. Chem. 92 (1988) 5270-5276.

61. K. Hofstadler, R. Bauer, S. Novalic, G. Heisler, New reactor design for photocatalytic wastewater treatment with $\mathrm{TiO}_{2}$ immobilized on fused-silica glass fibers: Photomineralization of 4-chlorophenol, Environ. Sci. Technol. 28 (1994) 670674, doi: https://doi.org/10.1021/es00053a021.

62. M. L. Sauer, D. F. J. Ollis, Acetone Oxidation in a Photocatalytic Monolith Reactor, Catal. 149 (1994) 81-91, doi: https:// doi.org/10.1006/jcat.1994.1274.

63. H. Lin, K. T. Valsaraj, Surface-enhanced Raman scattering and polarized photoluminescence from catalytically grown CdSe nanobelts and sheets, J. Appl. Electrochem. 35 (2005) 699-701, doi: https://doi.org/10.1021/ja044270j.

64. Z. Sun, J. Zhao, P. C. Y. Chow, K. Jiang, J. Zhang, Z. Zhu, J. Zhang, F. Huang, H. Yan Nonfullerene acceptor molecules for bulk heterojunction organic solar cells, Chem. Rev. 118 (2018) 3447-3507, doi. https://doi.org/10.1021/acs.chemrev.7b00535

65. L. Wang, W. Jiang, J. Zhan, Recent development in reactive synthesis of nanostructured bulk materials by spark plasma sintering, Int. J. Refract. Metals. Hard. Mater. 39 (2013) 103112, doi: https://doi.org/10.1016/j.ijrmhm.2013.01.017.

66. J. M. Coronado, The Keys of Success: $\mathrm{TiO}_{2}$ as a Benchmark Photocatalyst, u J. Coronado, F. Fresno, M. D. Hernández-Alonso, R. Portela (ur.), Design of Advanced Photocatalytic Materials for Energy and Environmental Applications, Springer-Verlag, London, 2013., str. 85-101, doi. https:// doi.org/10.1007/978-1-4471-5061-9_5.

67. H. de Lasa Novel Photocatalytic Reactors for Water and Air Treatment, u H. de Lasa, B. Serrano, M. Salaices, Photocatalytic Reaction Engineering, Springer, Boston, MA, 2005., str. 17-47, doi: https://doi.org/10.1007/0-387-27591-6_2.

68. A. J. Expósito, D. A. Patterson, W. S. W. Mansor, J. M. Monteagudo, E. Emanuelsson, I. Sanmartín, A. Durn, Antipyrine removal by $\mathrm{TiO}_{2}$ photocatalysis based on spinning disc reactor technology, J. Environ. Manag. 187 (2016) 504-512, doi: https://doi.org/10.1016/j.jenvman.2016.11.012.

69. S. Dutta, Wastewater treatment using $\mathrm{TiO}_{2}$-based photocatalysts, u H. Mustansar, A. Kumar Mishra (ur.), Handbook of Smart Photocatalytic Materials - Environment, Energy, Emerging Applications and Sustainability, 2020., str. 317-320, doi: https://doi.org/10.1016/B978-0-12-8190517.00010-5.

70. I. Boiarkina, S. Norris, D. A. Patterson, The case for the spinning disc reactor as a process intensification technology: Comparison to an annular reactor for the degradation of methylene blue, Chem. Eng. J. 225 (2013) 752-756, doi: https://doi.org/10.1016/j.cej.2013.03.125.

71. I. Boiarkina, S. Pedron, D. A. Patterson, An experimental and modelling investigation of the effect of the flow regime 
on the photocatalytic degradation of methylene blue on a thin film coated ultraviolet irradiated spinning disc reactor, Appl. Catal. B: Environ. 110 (2011) 14-18, doi: https://doi. org/10.1016/j.apcatb.2011.08.008.

72. T. Van Garven, G. Mul, J. Moulijn, A. Stankiewicz, A review of photocatalytic processes, Chem. Eng. Proc. 46 (2007) 781-788, doi: https://doi.org/10.1016/j.cep.2007.05.012.

73. I. Liu, L. A. Lawton, D. W. Bahnemann, L. Liu, B. Proft, P. K. J. Robertson, The photocatalytic decomposition of microcystin-LR using selected titanium dioxide materials, Chemosphere 76 (2009) 549-553, doi: https://doi. org/10.1016/j.chemosphere.2009.02.067.

74. J. M. Herrmann, J. Matos, J. Disdier, C. Guillard, J. Laine, S. Malato, Solar photocatalytic degradation of 4-chlorophenol using the synergistic effect between titania and activated carbon in aqueous suspension, Catal. Today 54 (1999) 255265, doi: https://doi.org/10.1016/S0920-5861(99)00187-X.

75. S. Malato, F. Fernández-Ibáñez, M. I. Maldonado, J. Blanco, W. Gernjak, Decontamination and disinfection of water by solar photocatalysis: recent overview and trends, Catal. Today 147 (2009) 1-59, doi: https://doi.org/10.1016/j.cattod.2009.06.018.

76. M. Meunier, J. Gamage, Z. Duvnjak, Z. Zhang, Design and Characterization of a Novel Rotating Corrugated Drum Reactor for Wastewater Treatment, Int. J. Photoenergy 10 (2010) 1-10, doi: https://doi.org/10.1155/2010/146743.

77. A. A. Donaldson, A. Ye, J. Gamage McEvoy, Z. Zhan, Rotating Corrugated Photoreactor Design: Experimental and Computational Analysis of $\mathrm{TiO}_{2}$-Based Photocatalysis, AIChE J. 59 (2013) 560-570, doi: https://doi.org/10.1002/aic.13829.

78. X. Yao, Y. Zhang, L. Du, J. Liu, J. Yao, Review of the applications of microreactors, Renew. Sust. Energ. Rev. 47 (2015) 519-528, doi: https://doi.org/10.1016/j.rser.2015.03.078.

79. R. Gorges, S. Meyer, G. Kreisel, Photocatalysis in microreactors, J. Photochem. Photobiol. A 167 (2004) 95-98, doi: https://doi.org/10.1016/j.jphotochem.2004.04.004.

80. Y. Matsushita, N. Ohba, S. Kumada, K. Sakeda, T. Suzuki, T. Ichimura, Photocatalytic reactions in microreactors, Chem. Eng. J. 135 (2008) 301-304, doi: https://doi.org/10.1016/j. cej.2007.07.045.

81. J. Arana, A. Pena Alonso, J. M. Dona Rodríguez, J. A. Herrera Melian, O. Díaz, J. Perez Pena, Comparative study of MTBE photocatalytic degradation with $\mathrm{TiO}_{2}$ and $\mathrm{Cu}-\mathrm{TiO}_{2}$, Appl. Catal. B-Environ. 78 (2008) 355-363, doi: https://doi. org/10.1016/j.apcatb.2007.09.023.

82. V. Augugliaro, E. García-Lopez, V. Loddo, S. Malato-Rodríguez, I. Maldonado, G. Marcì, Degradation of lincomycin in aqueous medium: Coupling of solar photocatalysis and membrane separation, Sol. Energy 79 (2005) 402-408, doi: https://doi.org/10.1016/j.solener.2005.02.020.

83. K. Azrague, P. Aimar, F. Benoit-Marquié, M. T. Maurette, A new combination of a membrane and a photocatalytic reactor for the depollution of turbid water, Appl. Catal. B-Environ. 72 (2007) 197-204, doi: https://doi.org/10.1016/j. apcatb.2006.10.007.

84. S. Jean Christophe, B. S. Bengu, Current and emerging membrane processes for water treatment, u: Membrane Technology: Volume 4: Membranes for Water Treatment, Volume 4, 2010., str. 53-91, https://doi.org/10.1002/9783527631407. ch3.

85. V. Tomašić, Monolitni katalizatori i reaktori: osnovne značajke, priprava i primjena, Kem. Ind. 53 (2004) 567-578, doi: https://doi.org/10.15255/KUI.2003.028.

86. R. Molinari, M. Borgese, E. Drioli, L. Palmisano, M. Schiavello, Hybrid processes coupling photocatalysis and membranes for degradation of organic pollutants in water, Catal. Today 75 (2002) 77-85, doi: https://doi.org/10.1016/S0920-87.

87. F. BosC, A. Ayral, C. J. Guizard, Mesoporous anatase coatings for coupling membraneseparation and photocatalyzed reactions, Membr. Sci. 265 (2005) 13-19, doi: https://doi. org/10.1016/j.memsci.2005.04.039.

88. K. E. Gustafson, R. M. J. Dickhut, Molecular Diffusivity of Polycyclic Aromatic Hydrocarbons in Aqueous Solution, Chem. Eng. Data 39 (1994) 281-285, doi: https://doi. org/10.1021/je00014a019.

89. URL: http://www.epa.gov/epaoswer/non-hw/industd/iwair tbd.htm (pristup 15. veljače 2020.).

90. R. Molinari, P. Argurio, L. Palmisano, 7 - Photocatalytic membrane reactors for water treatment, $u$ : Advances in Membrane Technologies for Water Treatment, 2015., str. 205-238, doi: https://doi.org/10.1016/B978-1-78242-1214.00007-1.

91. N. Li, Y. Tian, J. Zhang, Z. Sun, J. Zhao, J. Zhang, W. Zuo, Precisely-controlled modification of PVDF membranes with 3D $\mathrm{TiO}_{2} / \mathrm{ZnO}$ nanolayer: Enhanced anti-fouling performance by changing hydrophilicity and photocatalysis under visible light irradiation, J. Membr. Sci. 528 (2017) 359-368, doi: https://doi.org/10.1016/j.memsci.2017.01.048.

92. K. Fischer, A. Gawel, D. Rosen, M. Krause, A. A. Latif, J. Griebel, A. Prager, A. Schulze, Low-temperature synthesis of anatase/rutile/brookite $\mathrm{TiO}_{2}$ nanoparticles on a polymer membrane for photocatalysis, Catalysts 7 (2017) 209, doi: https:// doi.org/10.3390/catal7070209.

93. O. V. Artoshina, A. Rossouw, V. K. Semina, A. N. Nechaev, P. Y. Apel, Structural and physicochemical properties of titanium dioxide thin films obtained by reactive magnetron sputtering, on the surface of track-etched membranes, Pet. Chem. 55 (2015) 759-768, doi: https://doi.org/10.1134/ S0965544115100011.

94. J. H. Kim, M. K. Joshi, J. Lee, C. H. Park, C. S. Kim, Polydopamine-assisted immobilization of hierarchical zinc oxide nanostructures on electrospun nanofibrous membrane for photocatalysis and antimicrobial activity, J. Colloid Interface Sci. 513 (2018) 566-574, doi: https://doi.org/10.1016/j. jcis.2017.11.061.

95. N. Daels, M. Radoicic, M. Radetic, S. W. Van Hulle, K. De Clerck, Functionalisation of electrospun polymer nanofibre membranes with $\mathrm{TiO}_{2}$ nanoparticles in view of dissolved organic matter photodegradation, Sep. Purif. Technol. 133 (2014) 282-290, doi: https://doi.org/10.1016/j.seppur.2014.06.040.

96. Y. Shi, D. Yang, Y. Li, J. Qu, Z. Z.Yu, Fabrication of PAN@ $\mathrm{TiO}_{2} / \mathrm{Ag}$ nanofibrous membrane with high visible light response and satisfactory recyclability for dye photocatalytic degradation, Appl. Surf. Sci. 426 (2017) 622-629, doi: https://doi.org/10.1016/j.apsusc.2017.06.302.

97. E. Drioli, E. Fontananova, Catalytic membranes embedding selective catalysts: Preparation and applications, $\mathrm{u}$ P. Barbaro, F. Liguori (ur.), Heterogenized Homogeneous Catalysts for Fine Chemicals Production: Materials and Processes; Springer: Berlin, Germany, 2010., doi: https://doi. org/10.1007/978-90-481-3696-4_6.

98. S. Mozia, Photocatalytic membrane reactors (PMRs) in water and wastewater treatment. A review, Sep. Purif. Technol. 73 (2010) 71-79, doi: https://doi.org/10.1016/j.seppur.2010.03.021.

99. X. Zheng, Z. P. Shen, L. Shi, R. Cheng, D. Y. Yuan, Photocatalytic Membrane Reactors (PMRs) inWater Treatment: Configurations and Influencing Factors, Catalysts 7 (2017) 224, doi: https://doi.org/10.3390/catal7080224. 
100. R, Molinari, C. Lavorato, P. Argurio, Recent progress of photocatalytic membrane reactors in water treatment and in synthesis of organic compounds, Catal. Today 281 (2017) 144164, doi: https://doi.org/10.1016/j.cattod.2016.06.047.

101.N. H. H. Hairom, A. W. Mohammad, A. A. H. Kadhum, Effect of various zinc oxide nanoparticles in membrane photocatalytic reactor for Congo red dye treatment, Sep. Purif. Technol. 137 (2014) 74-81, doi: https://doi.org/10.1016/j. seppur.2014.09.027.

102.W. Y. Wang, A. Irawan, Y. Ku, Photocatalytic degradation of Acid Red 4 using a titanium dioxide membrane supported on a porous ceramic tube, Water Res. 42 (2008) 4725-4732, doi. https://doi.org/10.1016/j.watres.2008.08.021.

103.S. S. Chin, T. M. Lim, K. Chiang, A. G. Fane, Hybrid low-pressure submerged membrane photoreactor for the removal of bisphenol A, Desalination 202 (2007) 253-261, doi: https:// doi.org/10.1016/j.desal.2005.12.062.

104.S. S. Chin, T. M. Lim, K. Chiang, A. G. Fane, Factors affecting the performance of a low-pressure submerged membrane photocatalytic reactor, Chem. Eng. J. 130 (2007) 53-63, doi: https://doi.org/10.1016/j.cej.2006.11.008.

105.M. J. Benotti, B. D. Stanford, E. C.Wert, S. A. Snyder, Evaluation of a photocatalytic reactor membrane pilot system for the removal of pharmaceuticals and endocrine disrupting compounds from water, Water Res. 43 (2009) 1513-1522, doi: https://doi.org/10.1016/j.watres.2008.12.049.

106. P. Argurio, E. Fontananova, R. Molinari, E. Drioli, Photocatalytic Membranes in Photocatalytic Membrane Reactors, Processes 6 (2018) 1-10, doi: https://doi.org/10.3390/ pr6090162.

107.O. Iglesias, M. J. Rivero, A. M. Urtiaga, I. Ortiz, Membrane-based photocatalytic systems for process intensification, Chem. Eng. J. 305 (2016) 136-148, doi: https://doi. org/10.1016/j.cej.2016.01.047.

108. R. Molinari, L. Palmisano, V. Loddo, A. W. Morawski, Studies on various reactor configurations for coupling photocatalysis and membrane processes in water purification, J Membr Sci.
206 (2002) 399-415, doi: https://doi.org/10.1016/S03767388(01)00785-2.

109. K. Azrague, E. Puech-Costes, P. Aimar, M. T. Maurette, F. Benoit-Marquie, Membrane photoreactor (MPR) for the mineralisation of organic pollutants from turbid effluents, J. Membr. Sci. 258 (2005) 71-77, doi: https://doi.org/10.1016/j. memsci.2005.02.027.

110.H. F. Lin, K. T. Valsaraj, Reusable adsorbents for dilute solution separation, Sep. Purif. Technol. 28 (2002) 87-102, doi: https://doi.org/10.1016/S1383-5866(02)00017-5.

111.R. E. Marinangeli, D. F. Ollis, Photo-assisted heterogeneous catalysis with optical fibers, AIChE J. 28 (1982) 945-955, doi: https://doi.org/10.1002/aic.690280609.

112. T. V. Nguyen, J. C. S. Wu, Photoreduction of $\mathrm{CO}_{2}$ to fuels under sunlight using optical-fiber reactor, Sol. Energy Mater Sol. Cells. 92 (2008) 864-872, doi: https://doi.org/10.1016/J. SOLMAT.2008.02.010.

113.D. Spasiano, R. Marotta, S. Malato, P. Fernandez-lbanez, I. Di Somma, Solar photocatalysis: Materials, reactors, some commercial, and pre-industrialized applications. A comprehensive approach, Appl. Catal. B: Environ. 170-171 (2015) 91-111, doi: https://doi.org/10.1016/j.apcatb.2014.12.050.

114.Y. Abdel-Maksoud, E. Imam, E. Ramadan, $\mathrm{TiO}_{2}$ Solar Photocatalytic Reactor Systems: Selection of Reactor Design for Scale-up and Commercialization-Analytical Review, Catalysts 6 (2016) 1-26, doi. https://doi.org/10.3390/catal6090138.

115.D. Bahnemann, Photocatalytic water treatment: Solar energy applications, Sol. Energy 77 (2004) 450-454, doi: https:// doi.org/10.1016/j.solener.2004.03.031.

116. R. J. Braham, A. T. Harris, Reviews of major design and scaleup considerations for solar photocatalytic reactors, Ind. Eng. Chem. Res. 48 (2009) 8890-8905, doi: https://doi. org/10.1021/ie900859z.

117. Plataforma Solar de Almeria. Solar treatment of water facilities, http://www.psa.es/en/instalaciones/aguas.php (26. kolovoza 2020.). 


\section{SUMMARY \\ Intensification of Photocatalytic Processes for Water and Wastewater Treatment \\ Ivana Elizabeta Zelić, ${ }^{a}$ Vanja Gilja, ${ }^{a}$ Ivana Grčić, ${ }^{b}$ and Vesna Tomašića*}

The global economic crisis that has been reigning in the last decade has once again encouraged thinking about the need for "reindustrialization". Reindustrialization is an economic, social, environmental, and political process of managing national resources in order to revitalize industry and other economic activities, relying on the development and application of new and innovative technologies. Chemical engineering thereby has a crucial role. According to many scientists, the reindustrialization and development of the "industry for the future" will be based on three key areas: preservation and remediation of the environment, saving energy and encouraging the development of renewable energy sources, and protecting human health. This also highlights the need to adapt the higher education system to new industrial and economic challenges.

Today, we are confronted more and more with achievements that go beyond the framework of "traditional" chemical engineering, which are mainly based on the application of a new approach known as process intensification. Scientists and engineers are intensely working on discovering new process devices and techniques, making a major step forward by enabling the development of integrated, safer, more energy efficient, and environmentally friendly technologies. Due to scientific advancement and growing public interest, process intensification is gradually starting to stand out as a new discipline within chemical engineering.

Due to the scope of this issue, this paper illustrates some examples of advanced photocatalytic reactors developed using process intensification methodology, including rotating disk/drum photocatalytic reactors, microreactors, membrane reactors (with suspended and immobilized photocatalyst), optical fibre ceramic monoliths, and some representatives of the solar reactors. Research in this area represents a major challenge considering the possibility of application of such systems in solving global environmental problems, primarily those related to water and wastewater treatment, including the removal of persistent organic compounds and pathogenic microorganisms from water resources.

\section{Keywords}

Process intensification, photocatalytic process, water treatment, advanced oxidation processes, reactor designs

${ }^{a}$ Faculty of Chemical Engineering and

Technology, University of Zagreb

Marulićev trg 19, 10000 Zagreb, Croatia

${ }^{\mathrm{b}}$ Geotechnical Faculty, University of Zagreb

Hallerova aleja 7, 42000 Varaždin, Croatia

Review

Received September 3, 2020

Accepted November 16, 2020 